\title{
Black Carbon and Particulate Matter Concentrations in Eastern Mediterranean Urban Conditions: An Assessment Based on Integrated Stationary and Mobile Observations
}

\author{
Tareq Hussein $1,2, * \mathbb{C}$, Shatha Suleiman Ali Saleh ${ }^{1}$, Vanessa N. dos Santos ${ }^{2}$, \\ Huthaifah Abdullah ${ }^{3}$ and Brandon E. Boor ${ }^{4,5}$ \\ 1 Department of Physics, The University of Jordan, Amman 11942, Jordan; shatha.alisaleh@gmail.com \\ 2 Institute for Atmospheric and Earth System Research (INAR), University of Helsinki, PL 64, \\ FI-00014 UHEL Helsinki, Finland; vanessa.nogueira@bsc.es \\ 3 Department of Mechanical Engineering, Osaka University, Suita 565-0871, Osaka, Japan; \\ hudaifa_ahmad@yahoo.com \\ 4 Lyles School of Civil Engineering, Purdue University, West Lafayette, IN 47907, USA; bboor@purdue.edu \\ 5 Center for High Performance Buildings, Ray W. Herrick Laboratories, Purdue University, West Lafayette, \\ IN 47907, USA \\ * Correspondence: tareq.hussein@helsinki.fi
}

Received: 7 May 2019; Accepted: 4 June 2019; Published: 13 June 2019

\begin{abstract}
There is a paucity of comprehensive air quality data from urban areas in the Middle East. In this study, portable instrumentation was used to measure size-fractioned aerosol number, mass, and black carbon concentrations in Amman and Zarqa, Jordan. Submicron particle number concentrations at stationary urban background sites in Amman and Zarqa exhibited a characteristic diurnal pattern, with the highest concentrations during traffic rush hours $\left(2-5 \times 10^{4} \mathrm{~cm}^{-3}\right.$ in Amman and $2-7 \times 10^{4} \mathrm{~cm}^{-3}$ in Zarqa). Super-micron particle number concentrations varied considerably in Amman (1-10 $\left.\mathrm{cm}^{-3}\right)$. Mobile measurements identified spatial variations and local hotspots in aerosol levels within both cities. Walking paths around the University of Jordan campus showed increasing concentrations with proximity to main roads with mean values of $8 \times 10^{4} \mathrm{~cm}^{-3}, 87 \mu \mathrm{g} / \mathrm{m}^{3}$, $62 \mu \mathrm{g} / \mathrm{m}^{3}$, and $7.7 \mu \mathrm{g} / \mathrm{m}^{3}$ for submicron, $\mathrm{PM}_{10}, \mathrm{PM}_{2.5}$, and black carbon (BC), respectively. Walking paths in the Amman city center showed moderately high concentrations (mean $10^{5} \mathrm{~cm}^{-3}, 120 \mu \mathrm{g} / \mathrm{m}^{3}$, $85 \mu \mathrm{g} / \mathrm{m}^{3}$, and $8.1 \mu \mathrm{g} / \mathrm{m}^{3}$ for submicron aerosols, $\mathrm{PM}_{10}, \mathrm{PM}_{2.5}$, and black carbon, respectively). Similar levels were found along walking paths in the Zarqa city center. On-road measurements showed high submicron concentrations $\left(>10^{5} \mathrm{~cm}^{-3}\right)$. The lowest submicron concentration $\left(<10^{4} \mathrm{~cm}^{-3}\right)$ was observed near a remote site outside of the cities.
\end{abstract}

Keywords: urban air quality; ultrafine particles; human exposure; urban aerosols; Middle East and North Africa (MENA)

\section{Introduction}

Urban areas represent concentrations of humans and their activities; and therefore, cities exhibit the highest levels of pollution leading to significant environmental impacts and adverse health effects [1]. Air pollution is not confined to a particular geographical location or where it was emitted, as it can be transported by thousands of kilometers, impacting other areas. Thus far, more than three thousand different anthropogenic air pollutants have been identified in urban areas. Many of them are related to combustion sources, such as traffic activities and biomass burning. The complex nature of urban air 
pollution has prompted attempts to quantify the levels of air pollution in cities around the globe and the associated impacts on human respiratory and cardiovascular health. Quantification can vary from extensive short-term measurement campaigns to continuous long-term monitoring; each approach has advantages and disadvantages.

Long-term monitoring is usually performed at a stationary and sustainable measurement site, such as Global Atmospheric Watch (GAW) stations; Aerosol Robotic Network (AERONET) stations; Integrated Carbon Observation System (ICOS); Aerosols, Clouds, and Trace Gases Research Infrastructure (ACTRIS); Station for Measuring Ecosystem-Atmosphere Relations (SMEAR); and US Environmental Protection Agency (EPA) monitoring sites. Short-term measurement campaigns are usually performed over a period of several days to a few months and are typically arranged to sample air pollution at a stationary location. In general, stationary monitoring stations are valuable for assessing the local state of the environment, but the number of stations is a limiting factor to accurately describe large-scale spatial distributions and their temporal trends. Recently, the global SMEAR has emerged to establish more than a thousand monitoring stations following the SMEAR concept developed in Finland [2].

Recently, the concept of mobile experimental setups has become increasingly common and useful in quantifying air pollution with high spatiotemporal resolution. One of the first concepts of mobile laboratories was introduced in 1990 by Aerodyne Research Inc. (ARI), in collaboration with Washington State University (WSU) and the University of New Hampshire (UNH). This mobile laboratory was used to quantify emissions of greenhouse gases from a variety of urban/industrial points and area emission sources [3]. Since 2000, many variants of mobile laboratories have emerged such as the PSI, TRAKER, SNIFFER, EMMA, AERO-TRAM, ML, PMetro, and TAPL, among others [4-7]. The TRAKER was introduced in 2003 to measure road dust emissions; it was improved in the subsequent setups [8-12]. A modified TRAKER concept was later adopted by some research groups such as the SNIFFER in Finland [13-18] and EMMA in Sweden [19,20]. In Germany, the AERO-TRAM is a mobile laboratory setup assembled onboard of a tram [21]. In Italy, the PMetro is another mobile setup assembled on the roof of a metro carriage [22]. These mobile laboratory concepts varied in instrument setup according to application.

In practice, the mobile laboratory setup has become less expensive, more compact, more widespread, and follows advances in air quality instrument technology and development of low-cost portable instruments. For example, the mobile laboratory concept was adopted in light-weight airplanes, passenger cars, on bikes, on baby strollers, and even inside backpacks [23-30]. Setups have become even more affordable and compact after introducing low-cost sensors, advanced data management, novel modelling tools, and fast communication networks [31]. This recent advancement in technology offers a promising future for air quality monitoring in cities, such as that outlined by the MegaSense concept [32].

In the Middle East and North Africa (MENA) region, quantification of air pollution has been given very little attention. Most of the literature on aerosols (particulate matter, PM) in the MENA has been focused on chemical characterization, with a special focus on long-range transport and sand dust storms [33]. In particular, there is very little published data on aerosol number concentrations and number size distributions down to the ultrafine regime (particles smaller than $100 \mathrm{~nm}$ ) in urban areas of the MENA [23,33-42]. Studies have shown that the smallest particle size fractions, which are best represented by aerosol number size distribution measurements, can adversely affect health [43-45].

There has been a continuous need to perform urban air pollution measurement campaigns in the MENA, and especially in Jordan. In this study, we aim to investigate concentrations of size-fractionated aerosols $(10 \mathrm{~nm}-10 \mu \mathrm{m})$ and black carbon in the urban atmosphere in Jordan. The measurements included a mobile setup (portable instruments, driving and walking) preceded by stationary measurement campaigns at two urban background sites (one in Amman and one in Zarqa). This study is an extension of our previous one by Hussein et al. [23] focusing on the two most 
populated cities, Amman and Zarqa. The outcomes of this study are to be utilized to assess human exposure in urban areas in Jordan.

\section{Materials and Methods}

\subsection{Country and City Descriptions}

Jordan is a developing country located in the Eastern Mediterranean region of MENA (Figure S1). It has a population of approximately 9.8 million (by end of year 2016) and has an area $\sim 89$ thousand $\mathrm{km}^{2}$. The country has a vast range of terrain, from high mountains in the west, agricultural activities in various regions, and a large area of desert/arid terrain in the southeastern part. Jordan has one of the world's lowest points at about $420 \mathrm{~m}$ bsl in the Jordan valley and has a small access to the Red Sea (Aqaba) in the south.

Amman and Zarqa are the most populated cities in Jordan (Figure S1), which emphasizes the importance of this study from the perspective of population exposure to urban air pollution. Amman, Zarqa, and inter-city populated areas are nearly contiguous due to the urbanization and an ever-increasing population. They are located in the northwestern part of Jordan and they accommodate more than $60 \%$ of the country's population. While Amman is the economic and political center of the country, Zarqa is one of the industrial centers. Therefore, air pollution originates from a vast range of sources; mainly emissions from traffic and industrial activities, in addition to local-scale household activities (e.g., heating in the winter). Airborne dust (super-micron aerosol $>1 \mu \mathrm{m}$ ) is also a major problem, not only in Jordan, but in the entirety of the MENA region [33]. In Jordan, long-range transport of airborne dust in the form of frequent sand and dust storms originates from three main regions: North Africa, the Arabian Peninsula, and the Levant during the spring and early summer. Local dust resuspension is mainly due to the expanding construction activities and the effect is observable during the autumn.

\subsection{Aerosol Measurements}

Aerosol measurements included both stationary measurement campaigns and mobile measurement campaigns (driving/walking/standing). Stationary measurements consisted of one parallel campaign, which was simultaneous with the mobile measurement campaigns, and three pre-campaigns. Table 1 lists all measurement campaigns and the following subsections provide additional details. The Supplementary Material also includes the routes of the mobile measurements

\subsubsection{Stationary Aerosol Measurement Campaigns}

Pre-campaigns Ia and Ib. Two pre-campaigns (6-18 March and 14-30 April 2014) were performed at the Department of Physics, which is located at the middle of the campus of the University of Jordan (JU). The campus $\left(32.0129^{\circ} \mathrm{N}, 35.8738^{\circ} \mathrm{E}\right)$ is a mixture of forest (pine and spruce trees) and educational buildings (3-4 floors). It can be classified as an urban background site. It is $\sim 10 \mathrm{~km}$ north of the city center in Amman. The surroundings of the campus are primarily a populated residential area and small streets. One of the main highways is parallel to the western side of the campus. During these campaigns, aerosol measurements consisted of submicron particle number concentrations performed with a Condensation Particle Counter (CPC, 3007-2, TSI). The sampling was with a $\sim 1 \mathrm{~m}$ copper tube ( $6 \mathrm{~mm}$ outer diameter) through the window of an office on the second floor; the sampling height was $\sim 6 \mathrm{~m}$ from the ground. The sampling time resolution was $1 \mathrm{~s}$. The data obtained from this campaign was used to calculate the diurnal pattern in submicron particle number concentrations and to provide reference data to interpret the mobile measurements performed in Amman city.

Pre-campaign II. This pre-campaign took place during 12-18 May 2014 on the roof-top of a building located in Ma'asom ( $\left.32.0653^{\circ} \mathrm{N}, 36.0782^{\circ} \mathrm{E}\right)$, which is in the northern part of Zarqa. This site can be classified as an urban background. The surrounding is mainly a populated residential area and small streets. Aerosol measurements consisted of the same sensors used in Pre-campaign Ia. 
The sampling was conducted with a $\sim 1 \mathrm{~m}$ copper tube ( $6 \mathrm{~mm}$ outer diameter); the sampling height was $\sim 6$ meters from the ground. The sampling time resolution was $1 \mathrm{~s}$. The data obtained from this campaign was used to calculate the diurnal pattern in submicron particle number concentrations and to provide reference data to interpret the mobile measurements performed in Zarqa city.

Table 1. Summary of stationary and mobile measurement campaigns.

\begin{tabular}{|c|c|c|c|c|c|c|c|}
\hline Type & Campaign & Date & Time Period & Distance & Location & City & Classification $^{1}$ \\
\hline \multirow[t]{4}{*}{ Stationary } & Pre-campaign Ia & March 6-18 & continuous & - & JU campus ${ }^{2}$ & Amman & UB \\
\hline & Pre-campaign $\mathrm{Ib}$ & April 14-30 & continuous & - & JU campus ${ }^{2}$ & Amman & UB \\
\hline & Pre-campaign II & May 12-18 & continuous & - & Ma'asom & Zarqa & UB \\
\hline & Parallel-campaign & May 29-June 4 & continuous & - & JU campus & Amman & UB \\
\hline \multirow[t]{14}{*}{ Mobile } & Walking Ia & May 29 & $15: 00-17: 39$ & $\sim 7 \mathrm{~km}$ & JU campus & Amman & $\mathrm{UB}^{3}+\mathrm{T}^{4}$ \\
\hline & Walking Ib & June 1 & $17: 29-18: 45$ & $\sim 7 \mathrm{~km}$ & JU campus & Amman & $\mathrm{UB}^{3}+\mathrm{T}^{4}$ \\
\hline & Walking Ic & June 1 & $11: 21-13: 03$ & $\sim 7 \mathrm{~km}$ & JU campus & Amman & $\mathrm{UB}^{3}+\mathrm{T}^{4}$ \\
\hline & Walking II & May 29 & $21: 45-00: 18$ & $\sim 4 \mathrm{~km}$ & City center & Amman & $\mathrm{U}+\mathrm{T}$ \\
\hline & Walking III & June 3 & $17: 55-19: 28$ & $\sim 5 \mathrm{~km}$ & City center & Zarqa & $\mathrm{U}+\mathrm{T}$ \\
\hline & Driving Ia & May 29 & $21: 11-21: 44$ & $\sim 17 \mathrm{~km}$ & Main roads & Amman & $\mathrm{U} / \mathrm{SU}+\mathrm{T}$ \\
\hline & Driving $\mathrm{Ib}$ & May 30 & 00:19-00:36 & $\sim 15 \mathrm{~km}$ & Main roads & Amman & $\mathrm{U} / \mathrm{SU}+\mathrm{T}$ \\
\hline & Driving IIa & June 1 & $19: 45-20: 21$ & $\sim 18 \mathrm{~km}$ & Main roads & Amman & $\mathrm{U} / \mathrm{SU}+\mathrm{T}$ \\
\hline & Driving IIb & June 1 & $21: 21-21: 14$ & $\sim 4 \mathrm{~km}$ & City center & Amman & $\mathrm{U}+\mathrm{T}$ \\
\hline & Driving IIC & June 1 & $21: 14-21: 27$ & $\sim 11 \mathrm{~km}$ & Main roads & Amman & $\mathrm{U} / \mathrm{SU}+\mathrm{T}$ \\
\hline & Driving III & June 2 & $16: 51-20: 00$ & $\sim 67 \mathrm{~km}$ & Main roads & Amman/Zarqa & $\mathrm{U} / \mathrm{SU} / \mathrm{R}+\mathrm{T}$ \\
\hline & Driving IV & June 4 & 11:01-11:52 & $\sim 2.3 \mathrm{~km}$ & Repair shop & Amman & $\mathrm{U}+\mathrm{T}$ \\
\hline & Remote Ia & May 30 & $00: 36-00: 51$ & $\sim 9 \mathrm{~km}$ & Beren & Amman/Zarqa & $\mathrm{R}$ \\
\hline & Remote Ia & May 30 & 01:14-01:24 & $\sim 9 \mathrm{~km}$ & Beren & Amman/Zarqa & $\mathrm{R}$ \\
\hline Standing & Remote Ib & May 30 & $00: 52-01: 13$ & - & Beren & Amman + Zarqa & $\mathrm{R}$ \\
\hline
\end{tabular}

Parallel campaign. This campaign took place during 29 May to 4 June 2014 at the same site of pre-campaigns Ia and $\mathrm{Ib}$ and occurred concurrently with the mobile measurement campaigns. The aerosol measurements consisted of size fractionated particle number concentrations made with a handheld optical particle counter (AeroTrak, TSI model 9306-V2). The sampling was with a $\sim 1 \mathrm{~m}$ copper tube (6 $\mathrm{mm}$ outer diameter) through the window of an office on the third floor; the sampling height was $\sim 10 \mathrm{~m}$ from the ground. The sampling time resolution was $10 \mathrm{~s}$. The aerosol data measured with the AeroTrak was mainly used to compare the concentrations of super-micron particles between this reference site and those made the mobile campaigns.

\subsubsection{Mobile Aerosol Measurement Campaigns_-Driving/Walking/Standing}

The mobile aerosol measurements were conducted during both driving or walking periods. In total, we drove and walked more than $200 \mathrm{~km}$. The experimental setup consisted of two portable Condensation Particle Counters (CPC, 3007-2 and P-Trak 8525, TSI), a laser photometer (DustTrak DRX 8533, TSI), a handheld optical particle counter (AeroTrak 9306-V2, TSI), and a portable aethalometer (microAeth, AethLabs model AE51). We used a Garmin GPS (eTrex 20) to record the speed and location of the mobile instruments with a $1 \mathrm{~s}$ time-resolution. We also monitored the temperature and relative humidity with a $10 \mathrm{~s}$ time resolution (Onset Computer Co. HOBO U12-012). All instrument clocks were synchronized each day. These instruments were setup for driving and walking sessions.

During the mobile-driving measurement campaigns, all instruments were situated on the back seat of a sedan car (Suzuki Kizashi, 2012) that had an overhead opening. While driving, we kept the overhead opening and the front windows fully opened, whereas the back windows were half opened. This ensured that cabinet indoor air was nearly fully mixed and had a high exchange rate with the outdoor air such that the aerosol measurements represented the outdoor air [23]. Therefore, we did not need special inlets for the aerosol instruments in this simple "mobile setup".

During the mobile-walking measurement campaigns, the portable instruments were put inside two textile shopping bags. Each bag was carried by a researcher while walking. The height of the bags 
was $\sim 1 \mathrm{~m}$ from the ground. The CPC and the P-Trak were carried in one bag, whereas the DustTrak and the AeroTrak were carried in the other bag. We used short sampling inlets (conductive silicon tubes, inner diameter $4 \mathrm{~mm}, \sim 5 \mathrm{~cm}$ length) that penetrated through the bag to sample the aerosols. The aethalometer, GPS logger, and the HOBO sensor (temperature and relative humidity) hung outside a backpack carried by one of the researchers.

We performed four main driving measurement campaigns to cover a vast range of Amman streets and roads in different areas (Table 1 and Figure S2). One short driving campaign was made in the vicinity of car repair shops in Amman. One driving scenario covered a large road network $(\sim 66 \mathrm{~km})$ connecting Amman and Zarqa. We also made a measurement campaign by driving and standing still (i.e., stationary) in a remote region (Beren) outside Amman and Zarqa. We had three walking scenarios (Table 1, Figure S3). The first one was repeated three times and it was around the campus of the University of Jordan. The second walking scenario was in Amman city center, whereas the third one was in Zarqa city center.

\subsubsection{Portable Aerosol Instruments}

The CPC 3007-2 has a cutoff size of $10 \mathrm{~nm}$ and it is capable of measuring total submicron particle number concentrations with diameters up to $1 \mu \mathrm{m}$. The maximum detectable concentration is $10^{5} \mathrm{~cm}^{-3}$ with $20 \%$ accuracy. The sampling flow rate in this type of CPC is $0.1 \mathrm{lpm}$ (inlet flow rate $0.7 \mathrm{lpm}$ ). The P-Trak 8525 is a similar particle counter with minor differences; according to the manufacturer, the cutoff size is $20 \mathrm{~nm}$ and the maximum concentration is $5 \times 10^{5} \mathrm{~cm}^{-3}$. The P-Trak was also operated with a $1 \mathrm{~s}$ time-resolution. The sampling flow rate in this type of P-Trak is $0.1 \mathrm{lpm}$ (inlet flow rate $0.7 \mathrm{lpm}$ ). We previously validated the cutoff size and the maximum detectable concentration in both the CPC and the P-Trak [23]; the measured cutoff electrical mobility diameter was found to be $9 \mathrm{~nm}$ and $22 \mathrm{~nm}$ for the CPC and the P-Trak, respectively (this agrees well with the nominal cutoffs provided by the manufacturer as $10 \mathrm{~nm}$ and $20 \mathrm{~nm}$, respectively). However, the measured maximum detectable concentration with both the CPC and the P-Trak was about $4 \times 10^{5} \mathrm{~cm}^{-3}$.

The AeroTrak 9306-V2 measures size-specific particle number concentrations within the optical diameter range of $0.3-25 \mu \mathrm{m}$ divided into 6-channels (user defined). We setup these channels as 0.3 , $0.5,1,2.5,10$, and $25 \mu \mathrm{m}$. The sampling time-resolution was $10 \mathrm{~s}$ at a flow rate of $2.83 \mathrm{lpm}$.

The DustTrak DRX 8533 measures PM mass concentrations in the diameter range of 0.1-15 $\mu \mathrm{m}$ with a maximum concentration limit of $150 \mathrm{mg} / \mathrm{m}^{3}$ [46]. It displays size segregated mass fractions for $\mathrm{PM}_{1}, \mathrm{PM}_{2.5}$, respirable, $\mathrm{PM}_{10}$, and total. The sampling flow rate in this type of DustTrak was $3 \mathrm{lpm}$. We set the time-resolution at $10 \mathrm{~s}$. The DustTrak's zero test was calibrated prior to the beginning of each mobile track using an external HEPA filter. The DustTrak was factory-calibrated with Arizona Road Dust (ARD, ISO 12103-1, A1 Dust, [46]). As such, differences in the optical (refractive index) and morphological properties between the ARD and the sample aerosol will affect the mass concentrations reported in this study.

The microAeth monitors black carbon (BC) mass concentrations based on changes in light attenuation at a wavelength of $880 \mathrm{~nm}$, as particles are collected on a disposable filter. The sample flow rate was $0.1 \mathrm{lpm}$ and a $2.5 \mu \mathrm{m}$ size selective inlet was used. We set the time-resolution at $30 \mathrm{~s}$. The filter was replaced each day prior to the measurements. The BC data were post-processed to remove any spurious spikes in the concentration (e.g., $>1000 \mu \mathrm{g} / \mathrm{m}^{3}$ ) that were associated with sudden vibration of the instrument. This type of monitor (i.e., microAeth AE51) was tested against a reliable type (AE31) and also for real-time performance in field measurements [47]. According to Cheng and Lin [47], negative BC levels may be present using AE51 at low actual BC levels or at a high time-resolution. Negative values can be eliminated very effectively by adopting the optimized noise-reduction averaging (ONA) algorithm.

Recently, the use of portable aerosol instruments has been growing. Some researchers have tested their performance in the laboratory, in the field, or by side-by-side comparison to more reliable instruments [46-52]. 


\subsection{Data Handling and Harmony}

The raw GPS data, aerosol database, and weather conditions were first checked for correctness and quality. We then converted the mobile databases to $1 \mathrm{~min}$ averages and harmonized it to a universal time-stamp. The $1 \mathrm{~min}$ processed database was then used to calculate the average concentrations during certain time periods related to specific walking/driving sessions. These concentrations were then compared to the corresponding concentrations measured at the reference site (JU campus). The CPC database measured at the stationary site was used to calculate the average diurnal patterns separately for workdays and weekends. These average diurnal patterns were used as our reference for the submicron particle number concentrations $\left(\mathrm{PN}_{1-0.01}\right)$ obtained from the mobile measurements.

Using several portable instruments that cover a wide size range and with different cutoff diameters makes it possible to derive particle number and mass concentrations in several size fractions. Therefore, we focused on the following size fractions: super-micron $(1-10 \mu \mathrm{m})$ particle number and mass concentrations and submicron $(0.01-1 \mu \mathrm{m})$ particle number concentrations with three fractions in the following particle diameter ranges: $10-25 \mathrm{~nm}, 25-300 \mathrm{~nm}$, and $0.3-1 \mu \mathrm{m}$. Specifically, the DustTrak recorded $\mathrm{PM}_{1}, \mathrm{PM}_{2.5}$, and $\mathrm{PM}_{10}$ from which we could calculate $\mathrm{PM}_{10-1}$. Likewise, we calculated $\mathrm{PN}_{0.025}-0.01$ from the difference between the concentrations measured with the CPC and the P-Trak. The $\mathrm{PN}_{1-0.3}$ was then calculated from the AeroTrak and the P-Trak measurements. Finally, the $\mathrm{PN}_{10-1}$ was obtained from the AeroTrak.

\section{Results}

\subsection{Average Concentrations at the Reference Sites-Urban Background}

\subsubsection{Submicron Aerosols}

Based on the pre-campaigns Ia and $\mathrm{Ib}$, which were performed at the urban background site in Amman (JU campus), the workday diurnal pattern (Figure 1a) of submicron particle number $\left(\mathrm{PN}_{1-0.01}\right)$ concentrations was characterized by the highest concentrations $\left(2 \times 10^{4}-5 \times 10^{4} \mathrm{~cm}^{-3}\right)$ during the morning traffic rush hours (6:00-10:00). The lowest concentrations $\left(\sim 1 \times 10^{4} \mathrm{~cm}^{-3}\right)$ were observed during 2:00-5:00, which was after midnight and before the morning traffic rush hours. The daytime concentrations started to decrease around 11:00 from $\sim 3.8 \times 10^{4} \mathrm{~cm}^{-3}$ reaching $\sim 2.5 \times 10^{3} \mathrm{~cm}^{-3}$ at midnight.

The diurnal pattern of $\mathrm{PN}_{1-0.01}$ at the urban background site in Zarqa (Ma'asom) was derived from the pre-campaign II. The workday diurnal pattern (Figure 1b) was also characterized by the highest concentrations (as high as $7 \times 10^{4} \mathrm{~cm}^{-3}$ ) during the morning traffic rush hours (06:00-09:00). A daytime peak was observed $\left(4.2 \times 10^{4} \mathrm{~cm}^{-3}\right)$ for the $\mathrm{PN}_{1-0.01}$ concentrations during 12:00-15:00 and a third peak (as high as $\left.4 \times 10^{4} \mathrm{~cm}^{-3}\right)$ was observed after 18:00. The lowest concentrations $\left(\sim 1 \times 10^{4} \mathrm{~cm}^{-3}\right)$ were observed during 02:00-05:00, which was the same period of the day observed for the lowest number concentrations at the urban background site in Amman (JU campus). In general, the concentrations at the Ma'asom urban background site was characterized by higher concentrations of submicron aerosols during the daytime. A reason for that would be the population density and traffic activity, which are generally higher at Ma'asom than the surroundings of the JU campus.

\subsubsection{Super-Micron Aerosols}

At the urban background site in Amman (JU campus) and based on the parallel measurement campaign, the super-micron particle number $\left(\mathrm{PN}_{10-1}\right)$ concentrations varied considerably from day to day (Figure 2). It was the lowest $\left(\sim 0.3 \mathrm{~cm}^{-3}\right)$ during the early morning of June 3rd, but the highest (exceeding $10 \mathrm{~cm}^{-3}$ ) during the last day (June 4th). During the first five days (29 May to 2 June), the super-micron particle number concentrations varied between $1 \mathrm{~cm}^{-3}$ and $10 \mathrm{~cm}^{-3}$. In one of our previous investigations based on a long-term analysis at an urban background site, the super-micron 
particle number concentrations typically varied within the range $1-2 \mathrm{~cm}^{-3}$, but could be higher than $5 \mathrm{~cm}^{-3}$ during dust episodes [33].

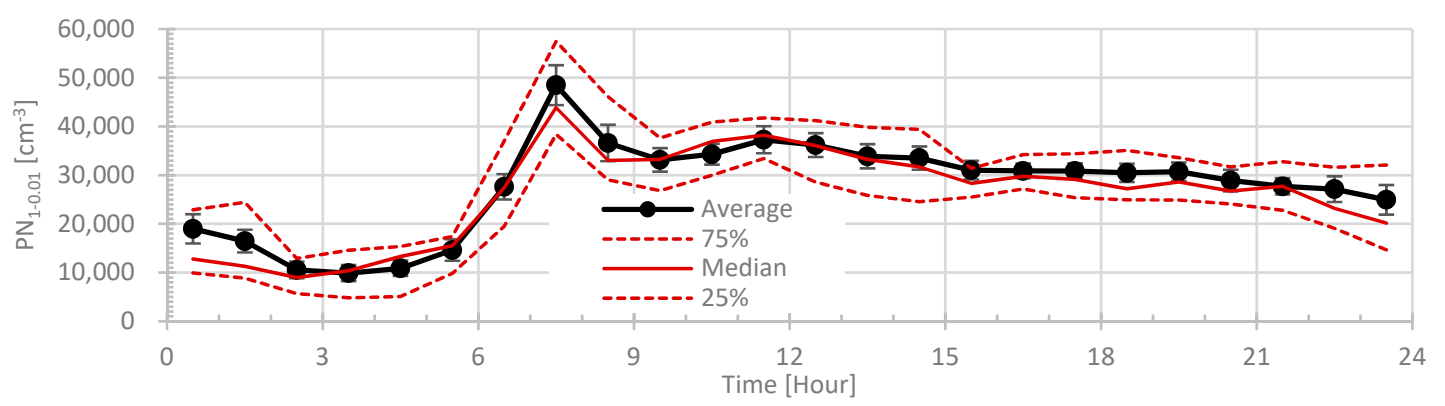

(a)

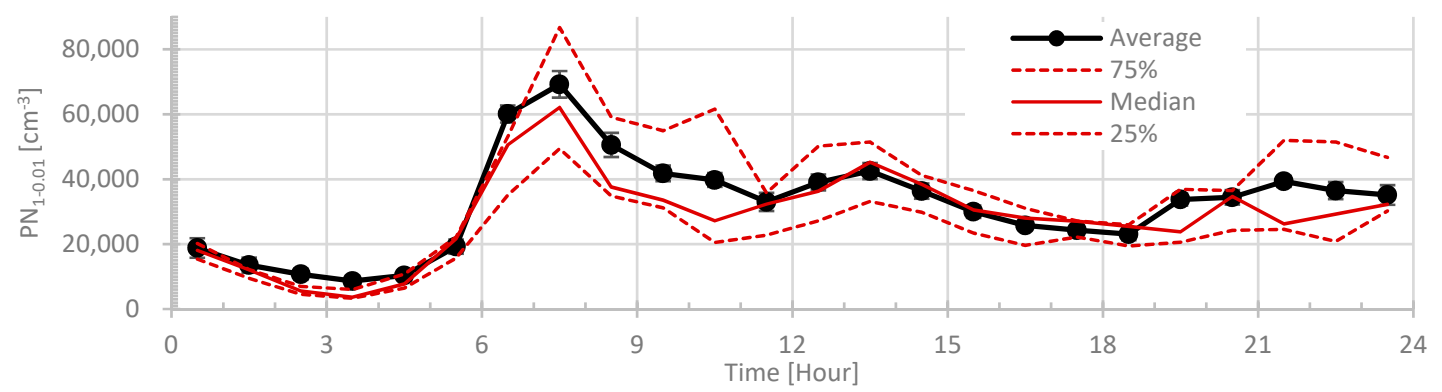

(b)

Figure 1. Workday diurnal patterns of submicron particle number concentrations $\left(\mathrm{PN}_{1-0.01}\right)$ measured at the reference urban background sites during the pre-campaigns: (a) the campus of the University of Jordan and (b) Ma'asom in Zarqa.

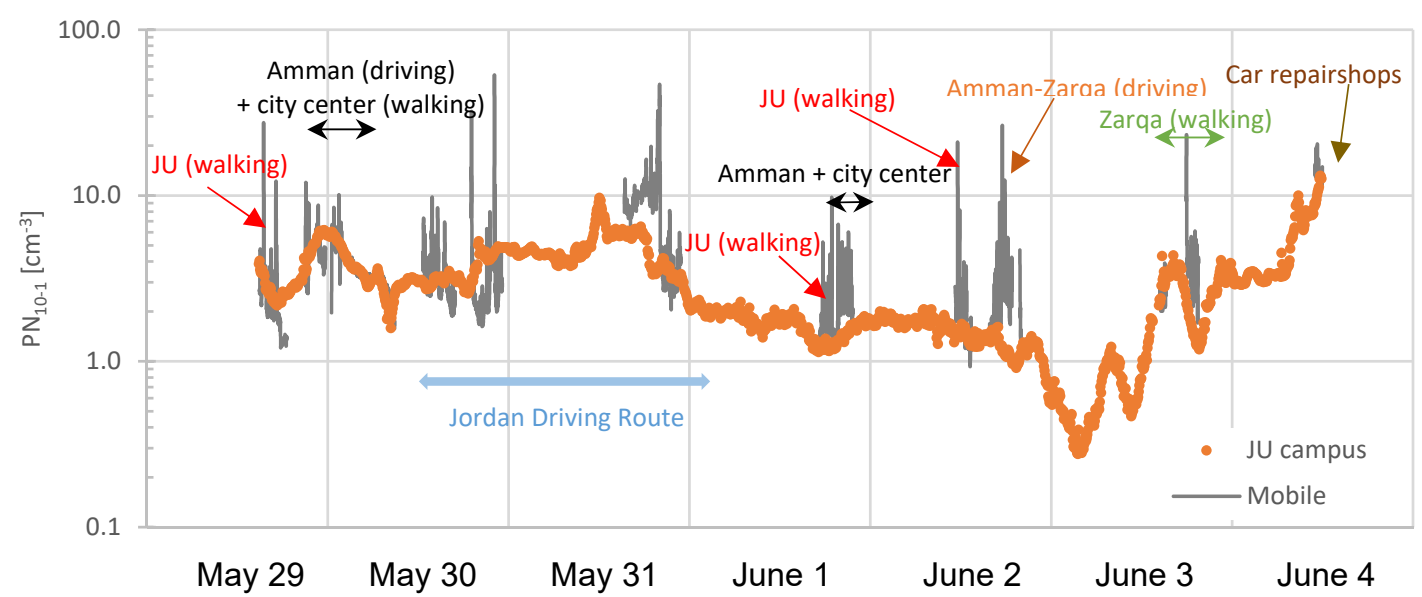

Figure 2. Super-micron particle number concentrations $\left(\mathrm{PN}_{10-1}\right)$ measured the reference urban background (campus of the University of Jordan) and compared to that measured with the mobile measurement campaigns.

\subsection{Remote Area (Beren) Outside Amman and Zarqa}

We chose a remote location outside the populated areas of Amman and Zarqa to provide insight into aerosol concentrations in a region not strongly affected by local pollution sources. This location was on a hill-top $\sim 17 \mathrm{~km}$ north of Amman city center and $\sim 15 \mathrm{~km}$ west of Zarqa city center. The surrounding area was slightly populated and there was one minor street at a distance $<500 \mathrm{~m}$ south of our chosen site. The campaign was made after midnight, when the air pollution is usually at its lowest level, in two different ways (Figure S2a): (1) while standing at this site and (2) while driving to and from the chosen site. 


\subsubsection{Off-Road Conditions in a Remote Area}

During standing, the mean $\mathrm{PN}_{1-0.01}$ concentration observed at this remote site was $\sim 6.6 \times 10^{3} \mathrm{~cm}^{-3}$ (Figure 3), which was slightly less than half what could be observed at the background sites (JU campus and Ma'asom) during the same time of the day. The mean $\mathrm{PN}_{10-1}$ concentration was $\sim 5 \mathrm{~cm}^{-3}$ (Table S1), which was slightly higher than what was observed at the JU campus (Table S3). The mean $\mathrm{PM}_{10}$ and $\mathrm{PM}_{2.5}$ concentrations were $66 \mu \mathrm{g} / \mathrm{m}^{3}$ and $34 \mu \mathrm{g} / \mathrm{m}^{3}$, respectively (Table S2). The mean BC concentration was about $0.5 \mu \mathrm{g} / \mathrm{m}^{3}$ (Table S2).

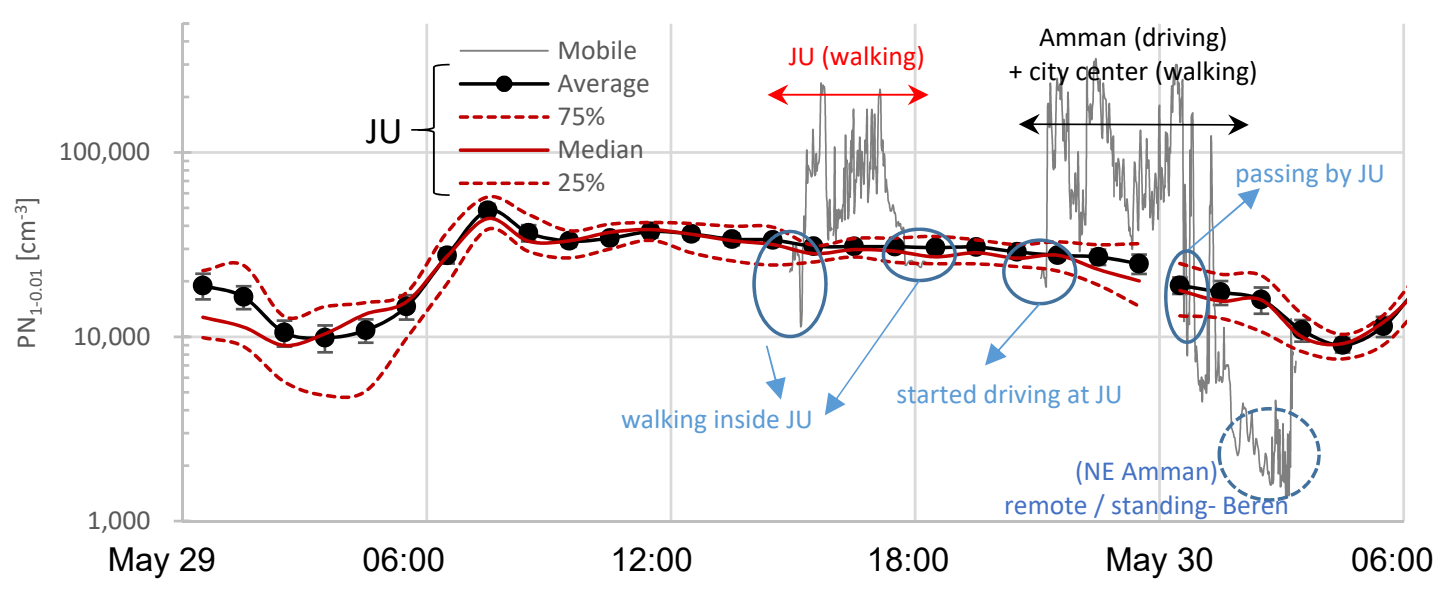

Figure 3. Submicron particle number concentrations $\left(\mathrm{PN}_{1-0.01}\right)$ measured during mobile campaigns on May 29th and continued on May 30th. The results are plotted along with the diurnal pattern observed at the reference urban background (campus of the University of Jordan).

\subsubsection{On-Road Conditions in a Remote Area}

During driving to/from this remote site, the concentrations were higher than those observed during standing. For example, the mean on-road $\mathrm{PN}_{1-0.01}$ concentration was $\sim 5 \times 10^{4} \mathrm{~cm}^{-3}$ (Figure 3), which was about 7.5 times that observed off-road at this remote site and about three times what could be observed at the background sites (JU campus and Ma'asom) during the same time of the day.

As for the super-micron aerosol fraction and the PM concentrations, the on-road concentrations were almost the same as those observed off-road at this remote area. For instance, the on-road mean $\mathrm{PN}_{10-1}$ concentration was $\sim 6 \mathrm{~cm}^{-3}$ (Table S1), whereas the mean $\mathrm{PM}_{10}, \mathrm{PM}_{2.5}$, and $\mathrm{BC}$ concentrations were 66,37 , and $1.6 \mu \mathrm{g} / \mathrm{m}^{3}$, respectively (Table S2). The large differences in the $\mathrm{PN}_{1-0.01}$ concentrations of submicron aerosols between on-road and off-road measurements in this remote area were consistent with previous near-road aerosol measurements [14]. The differences are thought to be due to the dispersion and dilution while aerosols are transported away from the road, where car emissions are concentrated the most, as illustrated by mobile laboratory measurements $[4,6,13]$.

\subsection{Exposure as an Urban Pedestrian}

The mobile measurement campaign enabled evaluation of spatial variations in urban air pollution exposure among pedestrians. The JU campus was taken as an example for higher educational institutions, where more than 50,000 students are regularly registered, and more than 6000 administration and faculty members work on campus. The city center in Amman is an example of a location where the local public and tourists spend the evening and enjoy the old town and historical heritage attractions. Another example for public exposure was the city center in Zarqa, which includes narrow street canyons with high population density and trade activities. In the following subsections, we present and discuss the air pollution exposure assessment for pedestrians in these three interesting setups. 


\subsubsection{Educational Campus and Its Surroundings}

The walking scenario at the JU campus and its surroundings was repeated three times (Figure S3a). We started walking from the Department of Physics, which was located in the middle of the campus, towards the main road, which was parallel to western side of the campus. We then walked south on the main road parallel to the western side of the campus, then entered the campus through the gate nearby the medical faculties and continued walking east towards the internal main street inside the campus. After that, we walked south towards the south gate and walked on the external roads counterclockwise parallel to the campus fence reaching the north gate. We finally entered the campus through the north gate and walked towards the Department of Physics.

The temporal variation of the $\mathrm{PN}_{10-1}$ concentrations measured during walking inside and around the university campus is shown in Figure 2, whereas those for the $\mathrm{PN}_{1-0.01}$ concentrations are found in Figures 3 and 4 . The overall mean $\mathrm{PN}_{10-1}$ concentration was $\sim 2.5 \mathrm{~cm}^{-3}$ (Table S1), which was slightly higher than what was observed at the stationary site on campus (Table S3). The overall mean $\mathrm{PN}_{1-0.01}$ concentration was $\sim 8 \times 10^{4} \mathrm{~cm}^{-3}$. The overall mean $\mathrm{PM}_{10}$ and $\mathrm{PM}_{2.5}$ concentrations were $87 \mu \mathrm{g} / \mathrm{m}^{3}$ and $62 \mu \mathrm{g} / \mathrm{m}^{3}$, respectively (Table S2). The mean BC concentration was approximately $7.7 \mu \mathrm{g} / \mathrm{m}^{3}$ (Table S2).

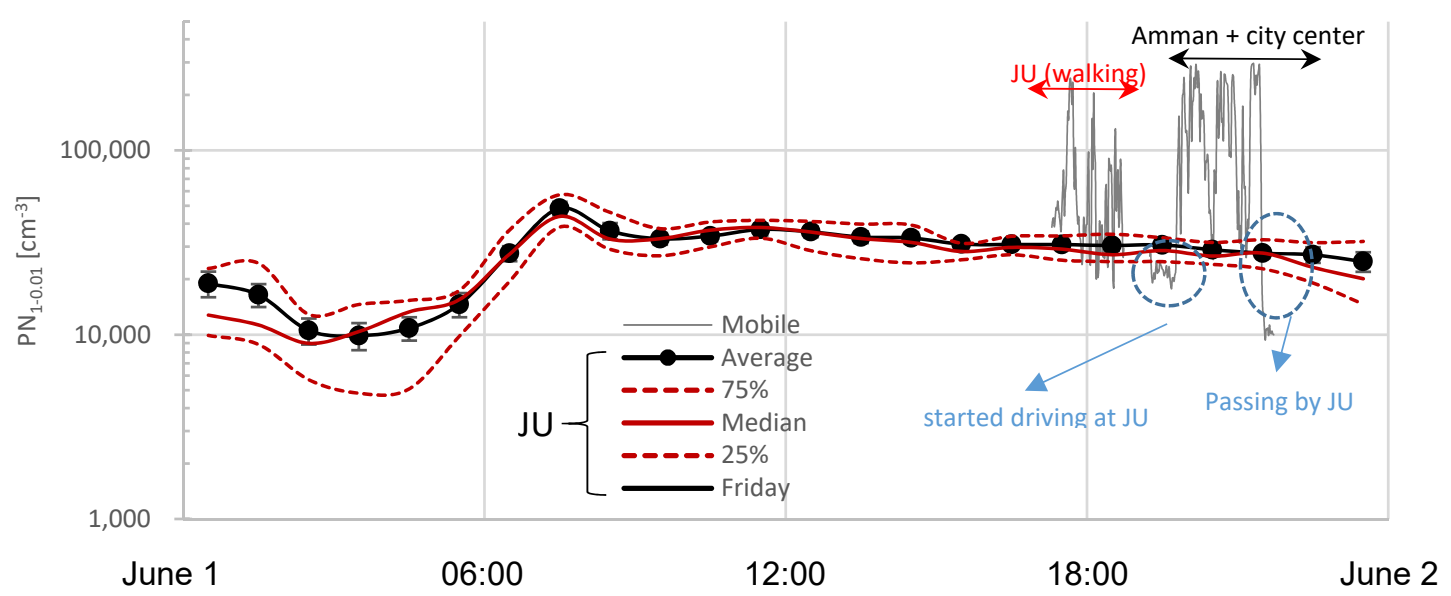

(a)

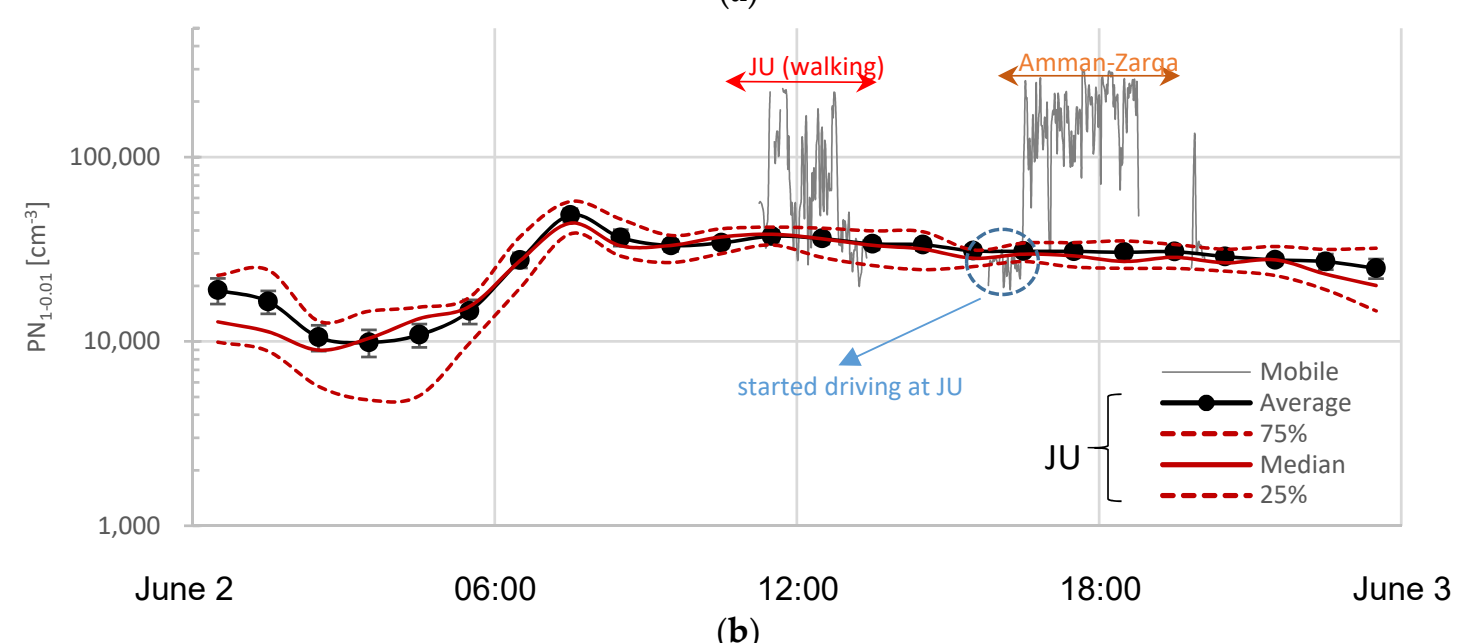

Figure 4. Submicron particle number concentrations $\left(\mathrm{PN}_{1-0.01}\right)$ measured during mobile campaigns on (a) June 1st and (b) June 2nd. The results are plotted along with the diurnal patterns observed at the reference urban background (campus of the University of Jordan).

As expected, the $\mathrm{PN}_{1-0.01}, \mathrm{PM}_{2.5}$, and $\mathrm{BC}$ concentrations showed a spatial variation inside the campus with increasing concentrations while approaching the campus fence from inside. The main reason was due to the closer proximity to the on-road traffic emissions. Interestingly, the $\mathrm{BC}$ mass 
fraction was more than $10 \%$ of the $\mathrm{PM}_{2.5}$. When compared to the diurnal pattern observed at the stationary site on the campus, the $\mathrm{PN}_{1-0.01}$ concentrations while walking inside the campus were generally within the quartiles of the $\mathrm{PN}_{1-0.01}$ diurnal pattern. However, most of the time the $\mathrm{PN}_{1-0.01}$ concentrations exceeded $10^{5} \mathrm{~cm}^{-3}$ while walking outside the campus. From an exposure point of view, the students, faculty, and staff are most likely to be exposed to high concentrations of air pollution. The matter becomes more concerning when commuting between the outside and inside of the campus.

\subsubsection{Leisure Time-Amman and Zarqa City Centers}

Walking in Amman city center and its neighborhood is a joy, not only for tourists, but also for locals. We selected the heart of the downtown, which is the lowest point between seven hills. The height difference can be more than $300 \mathrm{~m}$ in most of the cases. This makes it difficult for the ventilation of air pollution over the city center. The traffic congestion during daytime rush hours and late-night public activities exacerbates the air quality problem. The Amman city center is also a place for restaurants, which usually use intense cooking and grilling styles, and coffee shops, which usually offer water pipe smoking that requires special facilities for preparation and intensive coal burning. We spent a night walking in Amman city center (Figure S2a) and observed that the mean $\mathrm{PN}_{1-0.01}$ concentrations measured during walking in Amman city center exceeded $10^{5} \mathrm{~cm}^{-3}$ (Figure 3 and Table S1). The mean $\mathrm{PN}_{10-1}$ concentration was $\sim 5 \mathrm{~cm}^{-3}$ (Table S1), which was about the same at the urban background site (JU campus) during the same time of the walking session in the city center (Table S3). The mean $\mathrm{PM}_{10}$ and $\mathrm{PM}_{2.5}$ concentrations were $\sim 120 \mu \mathrm{g} / \mathrm{m}^{3}$ and $85 \mu \mathrm{g} / \mathrm{m}^{3}$, respectively (Table S2). The mean BC concentration was $\sim 8.1 \mu \mathrm{g} / \mathrm{m}^{3}$ (Table S2).

In Jordan, it is assumed that the air quality in Zarqa is worse than in Amman. Here, we try to clarify a part of that question. Zarqa has a variety of emission sources because it is the second most populated city in Jordan, is a center for industrial activities, and hosts the Jordan Petroleum Refinery Company (JOPETROL). Very close to Zarqa are landfill areas and Rusaifa, which is often considered a part of Zarqa and used to be an important site for phosphate mining. We performed one walking scenario in Zarqa city center (Figure S3b). The mean $\mathrm{PN}_{1-0.01}$ concentrations was higher than $7 \times 10^{4} \mathrm{~cm}^{-3}$ (Figure 5 and Table S1), which was apparently less than what was observed in Amman city center. The mean $\mathrm{PN}_{10-1}$ concentration measured in Zarqa city center was $\sim 4 \mathrm{~cm}^{-3}$ (Table S1), which was also less than what could be expected in Amman city center (Table S1). The mean $\mathrm{PM}_{10}$ and $\mathrm{PM}_{2.5}$ concentrations were $\sim 113 \mu \mathrm{g} / \mathrm{m}^{3}$ and $62 \mu \mathrm{g} / \mathrm{m}^{3}$, respectively (Table S2). The mean BC concentration was about $5.3 \mu \mathrm{g} / \mathrm{m}^{3}$ (Table S2).

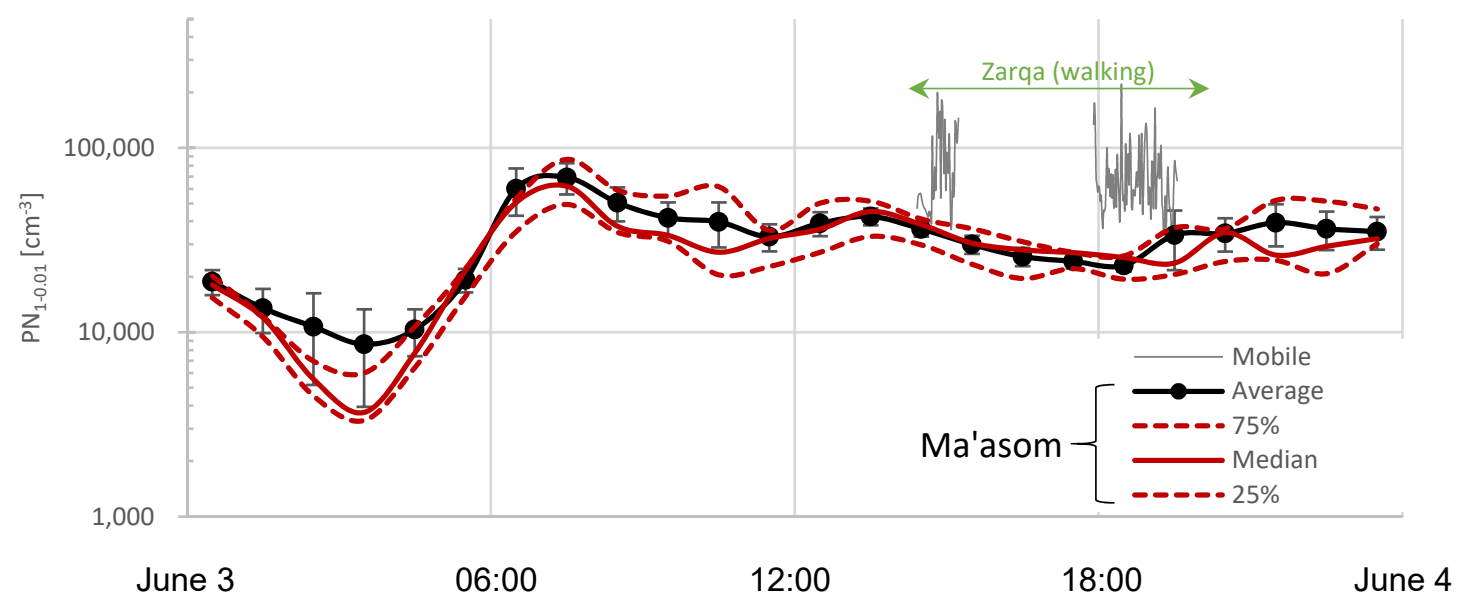

Figure 5. Submicron particle number concentrations $\left(\mathrm{PN}_{1-0.01}\right)$ measured during walking mobile campaign in Zarqa city center on June 3rd. The results are plotted along with the diurnal pattern observed at the reference urban background (Ma'asom in Zarqa). 


\subsection{In-Vehicle Exposure-Driving on Main Roads}

Jordan does not have an efficient public transport network. For example, the public buses and the service-car network barely cover the main roads in the well-built areas; the network is not updated to cover newly built areas in cities. Consequently, a large fraction of the population prefers to use their personal cars. This leads to traffic congestion on many streets in cities during different times of the day, contributing to elevated levels of air pollution and associated exposures. We completed several mobile scenarios to assess public exposure to air pollution on main roads in order to cover a large area across Amman and Zarqa (Figure S2).

The mean $\mathrm{PN}_{1-0.01}$ and $\mathrm{PN}_{10-1}$ concentrations measured during driving in Amman city center were $\sim 1.1 \times 10^{5} \mathrm{~cm}^{-3}$ and $\sim 2.7 \mathrm{~cm}^{-3}$ (Figure $4 \mathrm{a}$ and Table S1), whereas the mean $\mathrm{PM}_{10}, \mathrm{PM}_{2.5}$, and BC concentrations were $\sim 71 \mu \mathrm{g} / \mathrm{m}^{3}, 51 \mu \mathrm{g} / \mathrm{m}^{3}$, and $8.2 \mu \mathrm{g} / \mathrm{m}^{3}$, respectively (Table S2). In the vicinity of car repair shops, the mean $\mathrm{PN}_{1-0.01}$ and $\mathrm{PN}_{10-1}$ concentrations measured were $\sim 10^{5} \mathrm{~cm}^{-3}$ and $\sim 13.5 \mathrm{~cm}^{-3}$ (Figure 4a and Table S1), whereas the mean $\mathrm{PM}_{10}, \mathrm{PM}_{2.5}$, and BC concentrations were $\sim 238 \mu \mathrm{g} / \mathrm{m}^{3}$, $126 \mu \mathrm{g} / \mathrm{m}^{3}$, and $11.8 \mu \mathrm{g} / \mathrm{m}^{3}$, respectively (Table S2). Interestingly, the mean submicron particle number concentration in Amman city center was more than that observed at the car repair shop area, whereas the mean $\mathrm{PM}_{2.5}$ concentration behaved vice versa. A possible reason could be the density of emitted particulate matter was higher in the vicinity car repair shops when compared to traffic combustion emissions in the city center. At the car repair shops, the emitted particulate matter usually consisted of heavy metals and a wide range of organic compounds. Besides that, it appears the car repair shop area has high potential for local dust resuspension, as could be seen from the higher concentrations of the super-micron aerosol fraction when compared to the city center or the urban background site in Amman.

Driving on the main roads inside Amman and around the main roads connecting Amman and Zarqa had almost the same particle number concentrations (Figures 3 and 4 and Table S1); the mean $\mathrm{PN}_{1-0.01}$ and $\mathrm{PN}_{10-1}$ concentrations were $\sim 1.7 \times 10^{5} \mathrm{~cm}^{-3}$ and $\sim 3.6 \mathrm{~cm}^{-3}$, respectively. These were significantly higher than what was recorded during the same time periods at the urban background site in Amman (JU campus). As for the $\mathrm{PM}_{10}, \mathrm{PM}_{2.5}$, and $\mathrm{BC}$, the mean concentrations were, respectively, $89 \mu \mathrm{g} / \mathrm{m}^{3}, 60 \mu \mathrm{g} / \mathrm{m}^{3}$, and $15.98 \mu \mathrm{g} / \mathrm{m}^{3}$ on Amman main roads, whereas they were slightly higher $\left(108 \mu \mathrm{g} / \mathrm{m}^{3}, 71 \mu \mathrm{g} / \mathrm{m}^{3}\right.$, and $22.4 \mu \mathrm{g} / \mathrm{m}^{3}$, respectively) on the main roads connecting Amman and Zarqa.

\section{Discussion}

In urban areas, the diurnal pattern of $\mathrm{PN}_{1-0.01}$ is closely related to emissions from traffic and industrial activities. Usually, the traffic activity is characterized by two main rush hours (morning and afternoon) on workdays [53-57]. Such diurnal patterns have not only been reported in Jordan, but also in many other urban environments worldwide [35,53,58-66]; differences might be due to the variations related to traffic activities and vehicle type mix [6,16,18,25]. For instance, Rahman et al. [53] reported a workday $\mathrm{PN}_{1-0.01}$ diurnal pattern at an urban site in Brisbane (Australia); the concentrations were close to $9 \times 10^{3} \mathrm{~cm}^{-3}$ during the morning and afternoon rush hours. In Sao Paulo (Brazil), Backmann et al. [60] showed that the workday $\mathrm{PN}_{1-0.01}$ can be as high as $3.5 \times 10^{4} \mathrm{~cm}^{-3}$ during the daytime. In Helsinki (Finland), the $\mathrm{PN}_{1-0.01}$ was less than $1.5 \times 10^{4} \mathrm{~cm}^{-3}$ during the daytime and less than $5 \times 10^{3} \mathrm{~cm}^{-3}$ before the morning hours [55]. In a street canyon in Stockholm (Sweden), where air pollution is usually accumulated from traffic emissions, the $\mathrm{PN}_{1-0.01}$ was less than $9 \times 10^{4} \mathrm{~cm}^{-3}$ during the daytime [64]. In Copenhagen (Denmark), the $\mathrm{PN}_{1-0.01}$ was around $4 \times 10^{3} \mathrm{~cm}^{-3}$ during the morning traffic rush hours [67]. In Basel (Switzerland), the ultrafine particle (UFP, diameter $<100 \mathrm{~nm}$ ) was around $1.9 \times 10^{4} \mathrm{~cm}^{-3}$ during the morning traffic rush hours [68]. In megacities, the $\mathrm{PN}_{1-0.01}$ concentrations are expected to be more than these numbers due to the high population density and a much greater number of vehicles driven in the city. 
It is important to mention that the area in front of the main gate of the university campus is a place for public bus stations and a stopover for commuting transportation. Therefore, this can be considered as a hot spot for exposure to high concentrations of $\mathrm{PN}_{1-0.01}, \mathrm{PM}_{2.5}$, and $\mathrm{BC}$ [69-71]. For example, Velasco and Tan [69] reported that exposure at a bus stop can be, on average, 1500 times higher than that at ambient levels reported by the local authorities. In the same study, they illustrated that, on average, $60 \%$ of fine particles corresponded to $\mathrm{BC}$, in addition to a significant presence of particle-bound polycyclic aromatics. In another study by Cheng et al. [70], UFP number concentrations at bus terminals were more than $10^{5} \mathrm{~cm}^{-3}$, which is about 10 times higher than what can be found in the urban background. Based on such observations, they also concluded that the effects of UFPs on the health of passengers and workers must be addressed carefully at bus stops and terminals.

High exposure at bus stops is understood because of the commuters' close proximity to fresh fumes rich in particles emitted by passing, idling, and accelerating buses and motor vehicles [69,71]. This fact is not only limited to the specific area in front of the university main gate (as reported here in this study), but also can be generalized to central bus stations and bus stops on busy roads [70,71]. A concerning element of the exposure in the vicinity of bus terminals and stations is the magnitude of the particles being reported in the nucleation mode (i.e., diameter $<30 \mathrm{~nm}$ ), which is related to harmful health effects due to its high contents of freshly formed toxic air pollutants. The habit of smoking at bus stops amplifies the exposure limit [71].

The $\mathrm{PM}_{10}, \mathrm{PM}_{2.5}$, and $\mathrm{BC}$ on the main roads connecting Amman and Zarqa were slightly higher than that was observed on Amman main roads. That was mainly due to in the traffic fleet mixture, which was more dominated by lorries and big trucks on the main roads connecting Amman and Zarqa. Those lorries and big trucks were operated on diesel as a fuel. The Jordanian diesel grade is known for its high contents of sulfur and the diesel engine cars are not well maintained with respect to emission regulations [72]. This leads to excessive PM and BC emissions.

To help put our mobile measurement results in context, the following section summarizes selected prior studies that reported mobile measurements of aerosol number and mass concentrations and evaluated associated pedestrian and in-vehicle exposures. In the first place, it is worth noting that in-vehicle measurement can be representative for outdoor exposure if the setup is made such that the outdoor air penetrates efficiently into the car cabin. Recall that in our setup, we kept all windows and the rooftop open during driving, ensuring a high air exchange rate and maximum penetration factor. We verified that by comparing co-located measurements in-car and on-road [23]. This issue was also investigated in several previous studies focusing the indoor-to-outdoor relationship of aerosols [73-84]; here, indoor refers to "in-vehicle", whereas outdoor refers to "on-road". The studies agree on the fact that the indoor-to-outdoor ratio (I/O) of UFPs and concentrations is affected by the car speed and fan mode (low, medium, and full), as well as the type of air filter installed in the air-exchange system for the car cabin. In general, the I/O is also enhanced when the windows are opened.

In the literature, mobile measurements were performed in many different setups and scenarios: walking, biking, babies prams, in/out-vehicle, and different commuters and public transportation [85115]; see also Tables 2-4. In general, BC concentrations reported in this study were similar to those reported along mobile routes in Europe and North America, while being lower than what was measured in New Delhi, India. In general, fine particle concentrations are highly variable in the urban atmosphere because they are associated with traffic, proximate built environment characteristics, meteorological factors, time of day, and location $[85,95,96]$.

It is true that in urban areas people spend a short time in commuting microenvironments (when compared to other environments indoors and outdoors $[103,104])$. However, the exposure levels in commuting microenvironments, in many cases, are significantly higher than what can be found in ambient conditions (e.g., as could be clearly seen from the comprehensive literature review and discussion presented in this study). To confirm this, Knibbs et al. [105] presented a systematic review of UFP exposures in commuting microenvironments accounting for all possible modes (trips): ferry 
(13), rail (49) modes, bus (505), walking (524), cycling (599), automobile tunnel (333), and automobile non-tunnel (977).

Table 2. Summary of selected literature about mobile measurements of black carbon $\left(\mu \mathrm{g} / \mathrm{m}^{3}\right)$.

\begin{tabular}{|c|c|c|c|c|}
\hline & Country & City & Mobile Setup & BC \\
\hline Nazelle et al. [90] & Spain & Barcelona & Walking, biking, car/bus & $6-17$ \\
\hline Okokon et al. [89] & Greece & Thessaloniki & In-car ${ }^{1}$ & 11 \\
\hline Okokon et al. [89] & Finland & Helsinki & Bike, bus, and car & $3-8$ \\
\hline \multirow[t]{3}{*}{ Dons et al. [92] } & \multirow[t]{3}{*}{ Belgium } & \multirow[t]{3}{*}{ Flanders } & In train & 2.4 \\
\hline & & & Biking/walking & 3.6 \\
\hline & & & car/bus/metro & $6-7$ \\
\hline \multirow[t]{2}{*}{ Targino et al. [25] } & \multirow[t]{2}{*}{ Brazil } & \multirow[t]{2}{*}{ Mid-sized city } & On-bike ${ }^{2}$ & $\sim 8$ \\
\hline & & & On-bike ${ }^{3}$ & 6 \\
\hline \multirow[t]{5}{*}{ Ham et al. [94] } & \multirow[t]{5}{*}{ USA } & \multirow[t]{5}{*}{ Sacramento, California } & Car & 0.5 \\
\hline & & & Bus & 0.95 \\
\hline & & & Light-rail & 0.25 \\
\hline & & & Train & 2.54 \\
\hline & & & Bike & 0.71 \\
\hline Hankey and Marshall [96] & USA & Minneapolis, Minnesota & On-bike ${ }^{4}$ & $\sim 2.5(0.7)$ \\
\hline \multirow[t]{3}{*}{ MacNaughton et al. [87] } & \multirow[t]{3}{*}{ USA } & \multirow[t]{3}{*}{ Boston } & Bike lanes $^{5}$ & 2.4 \\
\hline & & & Bike paths ${ }^{6}$ & 1.7 \\
\hline & & & Background & 0.6 \\
\hline \multirow[t]{2}{*}{ Apte et al. [97] } & \multirow[t]{2}{*}{ India } & \multirow[t]{2}{*}{ New Delhi } & Auto-rickshaw ${ }^{7}$ & 42 \\
\hline & & & Auto-rickshaw ${ }^{8}$ & 85 \\
\hline \multirow[t]{5}{*}{ Li et al. [86] } & \multirow[t]{5}{*}{ China } & \multirow[t]{5}{*}{ Xuhui, Shanghai } & Taxi & 8.6 \\
\hline & & & Bus & 7.3 \\
\hline & & & Subway & 9.4 \\
\hline & & & Cycling & 6.6 \\
\hline & & & Walking & 5.6 \\
\hline
\end{tabular}

\footnotetext{
${ }^{1}$ Open windows. ${ }^{2}$ Near traffic. ${ }^{3}$ Flat terrain. ${ }^{4}$ Values were reported for a certain time, such as morning (afternoon)..$^{5}$ Bike lanes adjacent to traffic. ${ }^{6}$ Bike paths separated from vehicle traffic. ${ }^{7}$ This value was higher than ambient concentrations by $3.6 \times{ }^{8}$ These were short-duration peak concentrations, which were attributable to exhaust plumes of nearby vehicles.
}

According Knibbs et al. [105], the trip-weighted UFP exposure levels were $33.5 \times 10^{3}, 42.4 \times 10^{3}$, $45.1 \times 10^{3}, 46.9 \times 10^{3}, 48.7 \times 10^{3}$, and $56.9 \times 10^{3} \mathrm{~cm}^{-3}$ for bicycle, bus, automobile non-tunnel, rail, walk, and ferry. Exposures in an automobile tunnel reached as high as $3 \times 10^{5} \mathrm{~cm}^{-3}$. The UFP exposure levels for different modes of buses were also considered in that systematic review; the mean trip-weighted UFP exposure was as high as $50 \times 10^{3} \mathrm{~cm}^{-3}$ for buses running on diesel or diesel with crankcase filtration system (CFS). The exposure levels were lower (within the range $17 \times 10^{3}-28.6 \times 10^{3} \mathrm{~cm}^{-3}$ ) for buses running on biodiesel, compressed natural gas (CNG), electric, diesel with oxidation catalyst (DOC), diesel with diesel particulate filter (DPF), and diesel with crankcase filtration system (CFS).

The UFP exposure in buses shows a large variation among different urban environments worldwide, as illustrated by Lim et al. [106], who also updated the systematic review made by Knibbs et al. [105]. According to this updated review, the mean trip-weighted UFP exposure was in the range $7.4 \times$ $10^{3}-117.6 \times 10^{3} \mathrm{~cm}^{-3}$ (in general proportion to the population density) in many cities in Europe, 
USA, and Oceania. Jakarta (Indonesia), which is a megacity, exhibited very high UFP exposure levels reaching $4 \times 10^{5} \mathrm{~cm}^{-3}[106,107]$. On-bus exposure has been focused on public transportation, but school buses were rarely considered [108-110].

Table 3. Summary of selected literature about mobile measurements of particle number concentrations $\left(\times 10^{3} \mathrm{~cm}^{-3}\right)$.

\begin{tabular}{|c|c|c|c|c|c|}
\hline & Country & City & Mobile Setup & UFP & Fine \\
\hline Nazelle et al. [90] & Spain & Barcelona & $\begin{array}{l}\text { Walking, biking, } \\
\text { car/bus }\end{array}$ & $51-120$ & - \\
\hline \multirow[t]{3}{*}{ Okokon et al. [89] } & \multirow[t]{3}{*}{ Greece } & \multirow[t]{3}{*}{ Thessaloniki } & On-bus & - & 50 \\
\hline & & & In-car ${ }^{1}$ & - & - \\
\hline & & & In-car ${ }^{2}$ & - & 80 \\
\hline Okokon et al. [89] & Finland & Helsinki & Bike, bus, and car & - & $10-40$ \\
\hline Kumar et al. [88] & UK & Surrey & Babies prams & - & up to 10 \\
\hline \multirow[t]{4}{*}{ Ragettli et al. [68] } & \multirow[t]{4}{*}{ Switzerland } & \multirow[t]{4}{*}{ Basel } & In-car & 32 & - \\
\hline & & & On-bike & 23 & - \\
\hline & & & Walking & 19 & - \\
\hline & & & Public transportation & 14-19 & - \\
\hline \multirow[t]{3}{*}{ Panis et al. [91] } & \multirow[t]{3}{*}{ Belgium } & Brussels ${ }^{3}$ & On-bike/in-car & - & $\sim 30$ \\
\hline & & Wallonia $^{4}$ & On-bike/in-car & - & $\sim 12$ \\
\hline & & Flanders ${ }^{5}$ & On-bike/in-car & - & 10 \\
\hline Pattinson et al. [85] & N. Zealand & S. Auckland & On-bike & $5-40$ & - \\
\hline Quiros et al. [93] & USA & $\begin{array}{l}\text { S. Monica, } \\
\text { California }\end{array}$ & Walking ${ }^{6}$ & $12-28$ & - \\
\hline \multirow[t]{5}{*}{ Ham et al. [94] } & \multirow[t]{5}{*}{ USA } & \multirow[t]{5}{*}{$\begin{array}{l}\text { Sacramento, } \\
\text { California }\end{array}$} & Car & 7.9 & - \\
\hline & & & Bus & 13 & - \\
\hline & & & Light-rail & 5.5 & - \\
\hline & & & Train & 42 & - \\
\hline & & & Bike & 22 & - \\
\hline $\begin{array}{l}\text { Hankey and } \\
\text { Marshall [96] }\end{array}$ & USA & $\begin{array}{l}\text { Minneapolis } \\
\text { Minnesota }\end{array}$ & On-bike ${ }^{7}$ & - & $\begin{array}{c}\sim 3.3 \\
(\sim 1.7)\end{array}$ \\
\hline \multirow[t]{2}{*}{ Apte et al. [97] } & \multirow[t]{2}{*}{ India } & \multirow[t]{2}{*}{ New Delhi } & Auto-rickshaw ${ }^{8}$ & 280 & - \\
\hline & & & Auto-rickshaw ${ }^{9}$ & 650 & - \\
\hline
\end{tabular}

${ }^{1}$ Open windows. ${ }^{2}$ Closed windows. ${ }^{3}$ Urban. ${ }^{4}$ Louvain-la-Neuve (university town). ${ }^{5}$ Mol (small rural town).

${ }^{6}$ Lowest in evening and highest in morning. ${ }^{7}$ Values were reported for a certain time, such as morning (afternoon).

${ }^{8}$ This value was higher than ambient concentrations by $8.4 \times .{ }^{9}$ These were short-duration peak concentrations,

which were attributable to exhaust plumes of nearby vehicles.

It is also interesting to notice from this study, and also from the results reported in other studies, that exposure should not rely on a single metric, i.e., particulate mass and number concentrations, in addition to gaseous and specific types of aerosols, such as BC, volatile organic compounds (VOCs), heavy metals, etc. For example, the geometric mean (arithmetic mean) $\mathrm{PM}_{2.5}$ concentrations were 27.3 (35.8), 29.6 (33.4), 22.6 (27.3), and $28.0(58.3) \mu \mathrm{g} / \mathrm{m}^{3}$ in train, bus, automobile, and ferry modes, respectively [111]. The corresponding UFP concentrations were 2.8 (4.6), 8.4 (10.5), 7.5 (8.9), and 3.7 (5.5) $\times 10^{4} \mathrm{~cm}^{-3}$ for the train, bus, automobile, and ferry modes, respectively. 
Megacities exhibit the highest concentrations of air pollution. For instance, Apte et al. [97] measured real-time measurements of $\mathrm{PM}_{2.5}, \mathrm{BC}$, and UFP concentrations inside a common vehicle (auto-rickshaw) in New Delhi (India). They reported exposure concentrations that were higher than what can be found in other transportation microenvironments in other megacities; average concentrations were about $190 \mu \mathrm{g} / \mathrm{m}^{3}, 42 \mu \mathrm{g} / \mathrm{m}^{3}$, and $2.8 \times 10^{5} \mathrm{~cm}^{-3}$ for $\mathrm{PM}_{2.5}, \mathrm{BC}$, and UFP, respectively. These values were $1.5 \times, 3.6 \times$, and $8.4 \times$ higher than ambient concentrations, respectively. Short-duration peak concentrations, attributable to exhaust plumes from nearby vehicles, were greater than $300 \mu \mathrm{g} / \mathrm{m}^{3}$, $85 \mu \mathrm{g} / \mathrm{m}^{3}$, and $6.5 \times 10^{5} \mathrm{~cm}^{-3}$, respectively. In another study in Delhi, Goel et al. [98] reported exposure in different transportation modes and commuters; the on-road $\mathrm{PM}_{2.5}$ concentrations exceeded the ambient concentrations (ranging $130-250 \mu \mathrm{g} / \mathrm{m}^{3}$ ) by about $40 \%$ for walking; $30 \%$ for underground metro station, motorized two wheeler, open-windowed car, and auto rickshaw; $20 \%$ for air-conditioned open-windowed bus and bus stop; and $10 \%$ for bicycle. Interestingly, the $\mathrm{PM}_{2.5}$ concentrations were lower by $50 \%$ inside an air-conditioned car and $20 \%$ inside a metro rail carriage.

Table 4. Summary of selected literature about mobile measurements of particle mass concentrations $\left(\mu \mathrm{g} / \mathrm{m}^{3}\right)$.

\begin{tabular}{|c|c|c|c|c|c|}
\hline & Country & City & Mobile Setup & $\mathbf{P M}_{10}$ & $\mathbf{P M}_{2.5}$ \\
\hline Abi-Esber and El-Fadel [81] & Lebanon & Beirut & In-car ${ }^{1}$ & - & $38-93$ \\
\hline Nazelle et al. [90] & Spain & Barcelona & $\begin{array}{l}\text { Walking, biking, } \\
\text { car/bus }\end{array}$ & - & $21-35$ \\
\hline Okokon et al. [89] & Greece & Thessaloniki & On-bus & 131 & 85 \\
\hline Okokon et al. [89] & Finland & Helsinki & Bike, bus, and car & 40 & 30 \\
\hline Kumar et al. [88] & UK & Surrey & Babies prams & $\sim 40$ & $\sim 18$ \\
\hline \multirow[t]{3}{*}{ Panis et al. [91] } & \multirow[t]{3}{*}{ Belgium } & Brussels $^{4}$ & On-bike/in-car & $62 / 35$ & - \\
\hline & & Wallonia $^{5}$ & On-bike/in-car & $48 / 32$ & - \\
\hline & & Flanders 6 & On-bike/in-car & $72 / 75$ & - \\
\hline \multirow[t]{2}{*}{ Pattinson et al. [85] } & \multirow[t]{2}{*}{ N. Zealand } & \multirow[t]{2}{*}{ Auckland } & On-bike & $10-30$ & - \\
\hline & & & On-bike 9 & - & $\sim 8.5$ \\
\hline Quiros et al. [91] & USA & $\begin{array}{l}\text { S. Monica, } \\
\text { California }\end{array}$ & Walking ${ }^{10}$ & - & $6-11$ \\
\hline \multirow[t]{5}{*}{ Ham et al. [94] } & \multirow[t]{5}{*}{ USA } & \multirow[t]{5}{*}{$\begin{array}{l}\text { Sacramento, } \\
\text { California }\end{array}$} & Car & - & 7.1 \\
\hline & & & Bus & - & 7.5 \\
\hline & & & Light-rail & - & 5.7 \\
\hline & & & Train & - & 32.5 \\
\hline & & & Bike & - & 9.6 \\
\hline Boarnet et al. [95] & USA & Los Angeles & Commuters ${ }^{11}$ & - & $20-70$ \\
\hline Hankey and Marshall [96] & USA & $\begin{array}{l}\text { Minneapolis, } \\
\text { Minnesota }\end{array}$ & On-bike ${ }^{12}$ & - & $\sim 8.7(8.3)$ \\
\hline \multirow[t]{2}{*}{ Apte et al. [97] } & \multirow[t]{2}{*}{ India } & \multirow[t]{2}{*}{ New Delhi } & Auto-rickshaw 15 & - & 190 \\
\hline & & & Auto-rickshaw 16 & - & 300 \\
\hline
\end{tabular}

${ }^{1}$ Depending on the in-cabin ventilation mode. ${ }^{4}$ Urban. ${ }^{5}$ Louvain-la-Neuve (university town). ${ }^{6}$ Mol (small rural town). ${ }^{9}$ Overall mean. ${ }^{10}$ Lowest in evening and highest in morning. ${ }^{11}$ Different commuting types in different urban conditions. ${ }^{12}$ Values were reported for a certain time, such as morning (afternoon). ${ }^{15}$ This value was higher than ambient concentrations by $1.5 \times .{ }^{16}$ These were short-duration peak concentrations, which were attributable to exhaust plumes from nearby vehicles.

Qiu et al. [99] reported PM concentrations on four types of urban roads in the highly populated metropolitan area $\mathrm{Xi}^{\prime}$ an (China). The mean $\mathrm{PM}_{10}$ concentrations ranged from $\sim 145 \mu \mathrm{g} / \mathrm{m}^{3}$ at an 
expressway to $\sim 68 \mu \mathrm{g} / \mathrm{m}^{3}$ at a local road, whereas the $\mathrm{PM}_{2.5}$ concentrations ranged from $\sim 61 \mu \mathrm{g} / \mathrm{m}^{3}$ to $\sim 41 \mu \mathrm{g} / \mathrm{m}^{3}$, respectively. In the same city, Qiu et al. [100] reported that the average $\mathrm{PM}_{10}$ concentration was $4.5-348 \mu \mathrm{g} / \mathrm{m}^{3}$, whereas the average $\mathrm{PM}_{10}$ personal exposure concentrations were $75,12,123$, and $127 \mu \mathrm{g} / \mathrm{m}^{3}$, when commuting by subway, car, bus, and walking, respectively. As for $\mathrm{PM}_{2.5}$, the average personal concentration was $10-72 \mu \mathrm{g} / \mathrm{m}^{3}$ by the four commuting modes in the morning, with mean personal exposure concentration the highest when commuting by walking $\left(72 \mu \mathrm{g} / \mathrm{m}^{3}\right)$, followed by commuting by car $\left(67 \mu \mathrm{g} / \mathrm{m}^{3}\right)$, bus $\left(54 \mu \mathrm{g} / \mathrm{m}^{3}\right)$, and subway $\left(43 \mu \mathrm{g} / \mathrm{m}^{3}\right)$. In Beijing (China), Huang et al. [101] reported overall mean $\mathrm{PM}_{2.5}$ personal concentrations of 9-113 $\mu \mathrm{g} / \mathrm{m}^{3}$, with exposure ranges (mean) of $9-99 \mu \mathrm{g} / \mathrm{m}^{3}\left(32 \mu \mathrm{g} / \mathrm{m}^{3}\right), 13-102 \mu \mathrm{g} / \mathrm{m}^{3}\left(42 \mu \mathrm{g} / \mathrm{m}^{3}\right)$, and $19-113 \mu \mathrm{g} / \mathrm{m}^{3}\left(49 \mu \mathrm{g} / \mathrm{m}^{3}\right)$ when commuting by taxi, bus, and bicycle, respectively.

In Bogota (Colombia), Betancourt et al. [102] showed that the average BC concentrations were in the range $20-120 \mu \mathrm{g} / \mathrm{m}^{3}$ with commuters in motorized modes experienced significantly higher exposure concentrations than pedestrians and bicyclists. The highest average concentrations of $\mathrm{PM}_{2.5}$ $\left(186 \mu \mathrm{g} / \mathrm{m}^{3}\right), \mathrm{BC}\left(120 \mu \mathrm{g} / \mathrm{m}^{3}\right)$, and fine particle number concentrations $\left(2 \times 10^{5} \mathrm{~cm}^{-3}\right)$ were observed inside the city's Bus Rapid Transit system vehicles, whereas pedestrians and bicycle users in an open street configuration were exposed to the lowest average concentrations.

One of the most comprehensive studies was performed by Costabile et al. [112] to measure carbonaceous aerosols and their toxicity within a selected area in Rome, Italy. The study included a combination of: (1) fixed-site measurements (equipped with an extensive setup to monitor aerosol physiochemical properties), (2) mobile measurements with two TROPOS backpacks, which are a well-designed setup for mobile measurements with portable instruments [113], and (3) ten sites of road dust sampling. The air quality data was utilized for in-depth analysis of the toxicity of aerosols by including aerosol dosimetry, biomonitoring of polycyclic aromatic compounds (PAHs), and oxidative potential. An important objective and useful application of performing mobile measurement campaigns is to map air quality from a spatiotemporal prospective [114,115]. Indeed, this requires advanced data handling and modelling tools [32]. For instance, Hankey et al. [108] utilized on-bike mobile measurements (particle number and black carbon) as their air quality information portal and combined their data with an empirical model to create hourly air-quality maps for a small town in rural Appalachia, Virginia, USA. Their results were consistent with fixed-site and short-term sampling studies. Messier et al. [115] illustrated that air quality can be also mapped (with high spatial resolution) by utilizing Google Street View Cars (equipped with low-cost sensors for NO and black carbon), land use regression, and Monte Carlo analysis to map air quality in Oakland, California, USA. As such, a combination of information technology, computer science, geoscience, and environmental science can benefit from utilizing a combination of medium/low-cost sensing technology and novel modelling tools to provide valuable air quality information for the public [32].

\section{Conclusions}

In this study, we presented size-fractionated particulate matter concentrations (number, mass, and black carbon (BC)) measured with portable instruments in Amman and Zarqa, which are the two most populated cities in Jordan. The measurement scenarios included both stationary and mobile (driving and walking) sessions.

Number concentrations of ultrafine particles (UFPs, diameter $<100 \mathrm{~nm}$ ) were found to be spatiotemporally variant, with concentrations often exceeding $10^{5} \mathrm{~cm}^{-3}$ along mobile paths in Amman and Zarqa and increasing with proximity to main roadways and bus stations. The number concentrations in the 10-25 nm fraction were often within the range $2-5 \times 10^{4} \mathrm{~cm}^{-3}$. The mobile measurements demonstrate that pedestrian and in-vehicle UFP exposures in urban areas of Jordan were much greater than what would be predicted based on ambient air quality monitoring at stationary sites (University of Jordan campus in Amman and Ma'asom in Zarqa). In general, the levels of UFPs were found to be greater than those reported by mobile measurements made in European and North American cities, while similar to those reported for cities in India (New Delhi) and Colombia 
(Bogota). However, direct comparisons are difficult due to the differences in mobile sampling setups and durations, proximity to local sources, and measured size ranges.

The $\mathrm{PM}_{10}, \mathrm{PM}_{2.5}$, and $\mathrm{BC}$ concentrations exhibited similar spatiotemporal trends as UFP number concentrations, with levels greater near roads, bus stops, and industrial areas (e.g., car repair shops). The on-road observation revealed that $\mathrm{PM}_{10}$ and $\mathrm{PM}_{2.5}$ concentrations often exceeded $100 \mu \mathrm{g} / \mathrm{m}^{3}$ and $50 \mu \mathrm{g} / \mathrm{m}^{3}$, respectively. The BC concentrations were typically in the range of $5-15 \mu \mathrm{g} / \mathrm{m}^{3}$, with the highest levels $\left(22.4 \mu \mathrm{g} / \mathrm{m}^{3}\right.$, mean) measured while driving on roads between Amman and Zarqa.

This investigation provides valuable new data to advance our understanding of urban air pollution and associated human exposures in urban areas of Jordan, and more broadly, the MENA region. In Jordan, the population is exposed to a complex mixture of aerosols emitted from a vast range of sources, with the majority related to traffic and industrial activities. In order to improve urban air quality planning in Jordan, it is important to perform a combination of short-term and long-term (i.e., continuous) measurement campaigns.

According to the Jordanian E-AQ-AAQS (Environment—Air Quality—Ambient Air Quality Standards), the $24 \mathrm{~h}$ limit value for $\mathrm{PM}_{10}$ and $\mathrm{PM}_{2.5}$ are $120 \mu \mathrm{g} / \mathrm{m}^{3}$ and $65 \mu \mathrm{g} / \mathrm{m}^{3}$, respectively. According to our observations here, the $\mathrm{PM}_{10}$ concentrations in Amman touched their allowed limit, whereas the $\mathrm{PM}_{2.5}$ concentrations were often higher than their allowed limit. By all means, these concentrations are definitely alarming and they require more comprehensive investigations in the future. Nevertheless, a large fraction of the Jordanian population, especially in cities, is still breathing polluted air that has levels exceeding the World Health Organization (WHO) Air Quality Guidelines (AQG).

Supplementary Materials: Maps, driving routes, and statistical tables of particulate matter are available online at http://www.mdpi.com/2073-4433/10/6/323/s1.

Author Contributions: Conceptualization, validation, and project administration, T.H. and B.E.B.; methodology, H.A., T.H. and B.E.B.; data preparation, V.N.d.S.; investigation and data curation, S.S.A.S. and V.N.d.S.; writing—original draft preparation, T.H.; writing—review and editing, all authors; supervision, T.H.

Funding: This research was funded by the Deanship of Academic Research (DAR, project number 1516) at the University of Jordan. This intensive measurement campaign was part of a close collaboration between the University of Jordan, the Technical Research Centre of Finland (VTT), and the Institute for Atmospheric and Earth System Research (INAR / Physics, University of Helsinki) via ERA-PLANET (www.era-planet.eu), trans-national project SMURBS (www.smurbs.eu) (Grant Agreement n. 689443), funded under the EU Horizon 2020 Framework Programme and Academy of Finland via the Center of Excellence in Atmospheric sciences and NanoBioMass (project number 1307537). This manuscript was written and completed during the sabbatical leave of the first author's (Tareq Hussein) that was spent at the University of Helsinki and supported by the University of Helsinki during 2019.

Acknowledgments: This study and other urban research by the Aerosol Laboratory of the University of Jordan was recommended by the World Health Organization regional office in Amman.

Conflicts of Interest: The authors declare no conflict of interest.

\section{References}

1. Fenger, J. Urban air quality. Atmos. Environ. 1999, 33, 4877-4900. [CrossRef]

2. Kulmala, M. Build a global Earth observatory. Nature 2018, 553, 21-23. [CrossRef] [PubMed]

3. Klob, C.E.; Herndon, S.C.; McManus, J.B.; Shorter, J.H.; Zahniser, M.S.; Nelson, D.D.; Jayne, J.T.; Canagaratna, M.R.; Worsnop, D.R. Mobile laboratory with rapid response instruments for real-time measurements of urban and regional trace gas and particulate distributions and emission source characteristics. Environ. Sci. Technol. 2004, 38, 5694-5703. [CrossRef]

4. Simon, M.C.; Hudda, N.; Naumova, E.N.; Levy, J.I.; Brugge, D.; Durant, J.L. Comparisons of traffic-related ultrafine particle number concentrations measured in two urban areas by central, residential, and mobile monitoring. Atmos. Environ. 2017, 169, 113-127. [CrossRef] [PubMed]

5. Hsu, C.Y.; Lin, M.Y.; Chiang, H.C.; Chen, M.J.; Lin, T.Y.; Chen, Y.C. Using a mobile measurement to characterize number, surface area, and mass concentrations of ambient fine particles with spatial variability during and after a PM Event. Aerosol Air Qual. Res. 2016, 16, 1416-1426. [CrossRef] 
6. Kim, K.H.; Woo, D.; Lee, S.-B.; Bae, G.-N. On-road measurements of ultrafine particles and associated air pollutants in a densely populated area of Seoul, Korea. Aerosol Air Qual. Res. 2015, 15, 142-153. [CrossRef]

7. Bukowiecki, N.; Dommen, J.; Prévôt, A.S.H.; Richter, R.; Weingartner, E.; Baltensperger, U. A mobile pollutant measurement laboratory measuring gas phase and aerosol ambient concentrations with high spatial and temporal resolution. Atmos. Environ. 2002, 36, 5569-5579. [CrossRef]

8. Etyemezian, V.; Kuhns, H.; Nikolich, G. Precision and repeatability of the TRAKER vehicle-based paved road dust emission measurement. Atmos. Environ. 2006, 40, 2953-2958. [CrossRef]

9. Etyemezian, V.; Kuhns, H.; Gillies, J.; Chow, J.; Hendrickson, K.; McGown, M.; Pitchford, M. Vehicle-based road dust emissions measurement (Ш): Effect of speed, traffic volume, location, and season on PM10 road dust emissions in the Treasure Valley. Atmos. Environ. 2003, 37, 4583-4593. [CrossRef]

10. Etyemezian, V.; Kuhns, H.; Gillies, J.; Green, M.; Pitchford, M.; Watson, J. Vehicle-based road dust emissions measurements: I-Methods and calibration. Atmos. Environ. 2003, 37, 4559-4571. [CrossRef]

11. Kuhns, H.; Etyemezian, V.; Green, M.; Hendrickson, K.; McGrown, M.; Barton, K.; Pitchford, M. Vehicle based road dust emissions measurements-Part II: Effect of precipitation, wintertime road sanding, and street sweepers on inferred PM10 emission potentials from paved and unpaved roads. Atmos. Environ. 2003, 37, 4573-4582. [CrossRef]

12. Kuhns, H.; Etyemezian, V.; Landwehr, D.; MacDougall, C.; Pitchford, M.; Green, M. Testing re-entrained aerosol kinetic emissions from roads (TRAKER): A new approach to infer silt loading on roadways. Atmos. Environ. 2001, 35, 2815-2825. [CrossRef]

13. Pirjola, L.; Parviainen, H.; Hussein, T.; Valli, A.; Hameri, K.; Aalto, P.; Virtanen, A.; Keskinen, J.; Pakkanen, T.; Makela, J.; et al. Sniffer-A novel tool for chasing vehicles and measuring traffic pollutants. Atmos. Environ. 2004, 38, 3625-3635. [CrossRef]

14. Pirjola, I.; Paasonen, P.; Pfeiffer, D.; Hussein, T.; Hameri, K.; Koskentalo, T.; Virtanen, A.; Ronkko, T.; Keskinen, J.; Pakkanen, T.; et al. Dispersion of particles and trace gases nearby a city highway: Mobile laboratory measurements in Finland. Atmos. Environ. 2006, 40, 867-879. [CrossRef]

15. Pirjola, L.; Kupiainen, K.J.; Perhoniemi, P.; Tervahattu, H.; Vesala, H. Nonexhaust emission measurement system of the mobile laboratory SNIFFER. Atmos. Environ. 2009, 43, 4703-4713. [CrossRef]

16. Pirjola, L.; Lähde, T.; Niemi, J.; Kousa, A.; Rönkkö, T.; Karjalainen, P.; Keskinen, J.; Frey, A.; Hillamo, R. Spatial and temporal characterization of traffic emissions in urban microenvironments with a mobile laboratory. Atmos. Environ. 2012, 63, 156-167. [CrossRef]

17. Kupiainen, K.; Pirjola, L. Vehicle non-exhaust emissions from the tyre-road interface e effect of stud properties and traction sanding. Atmos. Environ. 2011, 45, 4141-4146. [CrossRef]

18. Lähde, T.; Niemi, J.V.; Kousa, A.; Rönkkö, T.; Karjalainen, P.; Keskinen, J.; Frey, A.; Hillamo, R.; Pirjola, L. Mobile particle and NOx emission characterization at helsinki downtown: Comparison of different traffic flow areas. Aerosol Air Qual. Res. 2014, 14, 1372-1382.

19. Hussein, T.; Johansson, C.; Karlsson, H.; Hansson, H.C. Factors affecting nontailpipe aerosol particle missions from paved roads: On-road measurements in Stockholm, Sweden. Atmos. Environ. 2008, 42, 688-702. [CrossRef]

20. Pirjola, L.; Johansson, C.; Kupiainen, K.; Stojiljkovic, A.; Karlsson, H.; Hussein, T. Road dust emissions from paved roads measured using different mobile systems. J. Air Waste Manag. 2010, 60, 1422-1433. [CrossRef]

21. Hagemann, R.; Corsmeier, U.; Kottmeier, C.; Rinke, R.; Wieser, A.; Vogel, B. Spatial variability of particle number concentrations and NOx in the Karlsruhe (Germany) area obtained with the mobile laboratory 'AERO-TRAM'. Atmos. Environ. 2014, 94, 341-352. [CrossRef]

22. Castellini, S.; Moroni, B.; Cappelletti, D. PMetro: Measurement of urban aerosols on a mobile platform. Measurement 2014, 49, 99-106. [CrossRef]

23. Hussein, T.; Boor, B.E.; Dos Santos, V.N.; Kangasluoma, J.; Petäjä, T.; Lihavainen, H. Mobile aerosol measurement in the eastern Mediterranean-A utilization of portable instruments. Aerosol Air Qual. Res. 2017, 17, 1775-1786. [CrossRef]

24. Xu, J.Y.; Jiang, H.; Zhao, H.R.; Stephens, B. Mobile monitoring of personal NOx exposures during scripted daily activities in Chicago, IL. Aerosol Air Qual. Res. 2017, 17, 1999-2009. [CrossRef]

25. Targino, A.C.; Gibson, M.D.; Krecl, P.; Rodrigues, M.V.C.; dos Santos, M.M.; de Paula Correa, M. Hotspots of black carbon and PM2.5 in an urban area and relationships to traffic characteristics. Environ. Pollut. 2016, 218, 475-486. [CrossRef] [PubMed] 
26. Bossche, V.J.; Peter, J.; Verwaeren, J.; Botteldooren, D.; Theunis, J.; De Baets, B. Mobile monitoring for mapping spatial variation in urban air quality: Development and validation of a methodology based on an extensive dataset. Atmos. Environ. 2015, 105, 148-161. [CrossRef]

27. Yang, F.; Kaul, D.; Wong, K.; Westerdahl, D.; Sun, L.; Ho, K.; Tian, L.; Brimblecombe, P.; Ning, Z. Heterogeneity of passenger exposure to air pollutants in public transport microenvironments. Atmos. Environ. 2015, 109, 42-51. [CrossRef]

28. Ruths, M.; von Bismarck-Osten, C.; Weber, C. Measuring and modelling the local-scale spatio-temporal variation of urban particle number size distributions and black carbon. Atmos. Environ. 2014, 96, 37-49. [CrossRef]

29. Wang, Y.; Xing, Z.; Zhao, S.; Zheng, M.; Mu, C.; Du, K. Are emissions of black carbon from gasoline vehicles overestimated? Real-time, in situ measurement of black carbon emission factors. Sci. Total Environ. 2016, 547, 422-428. [CrossRef] [PubMed]

30. Peters, J.; Theunis, J.; Van Poppel, M.; Berghmans, P. Monitoring PM10 and ultrafine particles in urban environments using mobile measurements. Aerosol Air Qual. Res. 2013, 13, 509-522. [CrossRef]

31. Ramanathan, N.; Lukac, M.; Ahmed, T.; Kar, A.; Siva, P.; Honles, T.; Leong, I.; Rehman, I.H.; Schauer, J.; Ramanathan, V. A cellphone based system for global monitoring of black carbon. Atmos. Environ. 2011, 45, 4481-4487. [CrossRef]

32. MegaSense. Available online: https://www.helsinki.fi/en/researchgroups/sensing-and-analytics-of-airquality (accessed on 7 June 2019).

33. Hussein, T.; Juwhari, H.; Al Kuisi, M.; Alkattan, H.; Lahlouh, B.; Al-Hunaiti, A. Accumulation and coarse mode aerosol concentrations and carbonaceous contents in the urban background atmosphere in Amman-Jordan. Arab. J. GeoSci. 2018, 11, 617. [CrossRef]

34. Hussein, T.; Halayka, M.; Abu Al-Ruz, R.; Abdullah, H.; Mølgaard, B.; Petäjä, T. Fine particle number concentrations in Amman and Zarqa during spring 2014. Jordan J. Phys. 2016, 9, 31-46.

35. Hussein, T.; Rasha, A.; Tuukka, P.; Heikki, J.; Arafah, D.; Kaarle, H.; Markku, K. Local air pollution versus short-range transported dust episodes: A comparative study for submicron particle number concentration. Aerosol Air Qual. Res. 2011, 11, 109-119. [CrossRef]

36. Hussein, T.; Betar, A. Size-fractionated number and mass concentrations in the urban background atmosphere during spring 2014 in Amman-Jordan. Jordan J. Phys. 2017, 10, 51-60.

37. Lihavainen, H.; Alghamdi, M.A.; Hyvärinen, A.; Hussein, T.; Neitola, K.; Khoder, M.; Abdelmaksoud, A.S.; Al-Jeelani, H.; Shabbaj, I.I.; Almehmadi, F.M. Aerosol optical properties at rural background area in Western Saudi Arabia. Atmos. Environ. 2017, 197, 370-378. [CrossRef]

38. Moustafa, M.; Mohamed, A.; Ahmed, A.-R.; Nazmy, H. Mass size distributions of elemental aerosols in industrial area. J. Adv. Res. 2015, 6, 827-832. [CrossRef] [PubMed]

39. Munir, S.; Habeebullah, T.M.; Seroji, A.R.; Gabr, S.S.; Mohammed, A.M.F.; Abu Saud, W.; Abdou, A.E.A.; Awad, A.H.; Gabr, S.S.; Mohammed, A.M.F.; et al. Modelling particulate matter concentrations in Makkah, applying a statistical modelling approach. Aerosol Air Qual. Res. 2013, 13, 901-910. [CrossRef]

40. Munir, S.; Habeebullah, T.M.; Seroji, A.R.; Gabr, S.S.; Mohammed, A.M.F.; Morsy, E.A. Quantifying temporal trends of atmospheric pollutants in Makkah (1997-2012). Atmos. Environ. 2013, 77, 647-655. [CrossRef]

41. Waked, A.; Seigneur, C.; Couvidat, F.; Kim, Y.; Sartelet, K.; Afif, C.; Borbon, A.; Formenti, P.; Sauvage, S. Modeling air pollution in Lebanon: Evaluation at a suburban site in Beirut during summer. Atmos. Chem. Phys. 2013, 13, 5873-5886. [CrossRef]

42. Tadros, M.T.Y.; Madkour, M.; El-Metwally, M. Size distribution of aerosol particles: Comparison between agricultural and industrial areas in Egypt. Renew. Energy 1999, 17, 339-354. [CrossRef]

43. Clifford, S.; Mazaheri, M.; Salimi, F.; Ezz, W.N.; Yeganeh, B.; Low-Choy, S.; Walker, K.; Mengersen, K.; Marks, G.B.; Morawska, L. Effects of exposure to ambient ultrafine particles on respiratory health and systemic inflammation in children. Environ. Int. 2018, 114, 167-180. [CrossRef] [PubMed]

44. Tobías, A.; Rivas, I.; Reche, C.; Alastuey, A.; Rodríguez, S.; Fernández-Camacho, R.; Sánchez de la Campa, A.M.; de la Rosa, J.; Sunyer, J.; Querol, X. Short-term effects of ultrafine particles on daily mortality by primary vehicle exhaust versus secondary origin in three Spanish cities. Environ. Int. 2018, 111, 144-151. [CrossRef] [PubMed] 
45. Chen, R.; Hu, B.; Liu, Y.; Xu, J.; Yang, G.; Xu, D.; Chen, C. Beyond PM2.5: The role of ultrafine particles on adverse health effects of air pollution. Biochim. Biophys. Acta-Gen. Subj. 2016, 1860, 2844-2855. [CrossRef] [PubMed]

46. Wang, X.; Chancellor, G.; Evenstad, J.; Farnsworth, J.; Hase, A.; Olson, G.; Sreenath, A.; Agarwal, J. A novel optical instrument for estimating size segregated aerosol mass concentration in real time. Aerosol Sci. Technol. 2009, 43, 939-950. [CrossRef]

47. Maricq, M.M. Monitoring Motor Vehicle PM Emissions: An Evaluation of Three Portable Low-Cost Aerosol Instruments. Aerosol Sci. Technol. 2013, 47, 564-573. [CrossRef]

48. Chung, A.; Chang, D.P.Y.; Kleeman, M.J.; Perry, K.; Cahill, T.A.; Dutcher, D.; McDougal, E.M.; Stroud, K. Comparison of real-time instruments used to monitor airborne particulate matter. J. Air Waste Manag. Assoc. 2001, 51, 109-120. [CrossRef] [PubMed]

49. Nyarku, M.; Mazaheri, M.; Jayaratne, R.; Dunbabin, M.; Rahman, M.M.; Uhde, E.; Morawska, L. Mobile phones as monitors of personal exposure to air pollution: Is this the future? PLOS ONE 2018, 13, e0193150. [CrossRef] [PubMed]

50. Cheng, Y.H.; Lin, M.H. Real-time performance of the micro-aeth AE51 and the effects of aerosol loading on its measurement results at a traffic site. Aerosol Air Qual. Res. 2013, 13, 1853-1863. [CrossRef]

51. Cai, J.; Yan, B.; Ross, J.; Zhang, D.; Kinney, P.L.; Perzanowski, M.S.; Jung, K.; Miller, R.; Chillrud, S.N. Validation of MicroAeth ${ }^{\circledR}$ as a black carbon monitor for fixed-site measurement and optimization for personal exposure characterization. Aerosol Air Qual. Res. 2014, 14, 1-9. [CrossRef]

52. Hämeri, K.; Koponen, I.K.; Aalto, P.P.; Kulmala, M. The particle detection efficiency of the TSI3007 condensation particle counter. Aerosol Sci. 2002, 33, 1463-1469. [CrossRef]

53. Rahman, M.M.; Mazaheri, M.; Clifford, S.; Morawska, L. Estimate of main local sources to ambient ultrafine particle number concentrations in an urban area. Atmos. Res. 2017, 194, 178-189. [CrossRef]

54. Goel, A.; Kumar, P. A review of fundamental drivers governing the emissions, dispersion and exposure to vehicle-emitted nanoparticles at signalised traffic intersections. Atmos. Environ. 2014, 97, 316-331. [CrossRef]

55. Hussein, T.; Mølgaard, B.; Hannuniemi, H.; Martikainen, J.; Järvi, L.; Wegner, T.; Ripamonti, G.; Weber, S.; Vesala, T.; Hämeri, K. Fingerprints of the urban particle number size distribution in Helsinki, Finland: Local versus regional characteristics. Boreal Environ. Res. 2014, 19, 1-20.

56. Padro-Martinez, L.T.; Patton, A.P.; Trull, J.B.; Zamore, W.; Brugge, D.; Durant, J.L. Mobile monitoring of particle number concentration and other traffic-related air pollutants in a near-highway neighbourhood over the course of a year. Atmos. Environ. 2012, 61, 253-264. [CrossRef] [PubMed]

57. Hussein, T.; Puustinen, A.; Aalto, P.P.; Mäkelä, J.M.; Hämeri, K.; Kulmala, M. Urban aerosol number size distributions. Atmos. Chem. Phys. 2004, 4, 391-411. [CrossRef]

58. Krecl, P.; Johansson, C.; Créso Targino, A.; Ström, J.; Burman, L. Trends in black carbon and sizeresolved particle number concentrations and veihicle emission factors under realworld conditions. Atmos. Environ. 2017, 165, 155-168. [CrossRef]

59. Hussein, T.; Alghamdi, M.A.; Khoder, M.; AbdelMaksoud, A.S.; Al-Jeelani, H.; Goknil, M.K.; Shabbaj, I.I.; Almehmadi, F.M.; Hyvärinen, A.; Lihavainen, H.; et al. Particulate matter and number concentrations of particles larger than $0.25 \mu \mathrm{m}$ in the urban atmosphere of Jeddah, Saudi Arabia. Aerosol Air Qual. Res. 2014, 14, 1383-1391. [CrossRef]

60. Backman, J.; Rizzo, L.V.; Hakala, J.; Nieminen, T.; Manninen, H.E.; Morais, F.; Aalto, P.P.; Siivola, E.; Carbone, S.; Hillamo, R.; et al. On the diurnal cycle of urban aerosols, black carbon and the occurrence of new particle formation events in springtime São Paulo, Brazil. Atmos. Chem. Phys. 2012, 12, 11733-11751. [CrossRef]

61. Chang, S.C.; Chou, C.C.K.; Chan, C.C.; Lee, C.T. Temporal characteristics from continuous measurements of PM2.5 and speciation at the taipei aerosol supersite from 2002 to 2008. Atmos. Environ. 2010, 44, 1088-1096. [CrossRef]

62. Yu, T.Y. Characterization of ambient PM2.5 concentrations. Atmos. Environ. 2010, 44, 2902-2912. [CrossRef]

63. Wu, Z.; Hu, M.; Lin, P.; Liu, S.; Wehner, B.; Wiedensohler, A. Particle number size distribution in the urban atmosphere of Beijing, China. Atmos. Environ. 2008, 42, 7967-7980. [CrossRef]

64. Olivares, G.; Johansson, C.; Strom, J.; Hasson, H.C. The role of ambient temperature for particle number concentrations in a street canyon. Atmos. Environ. 2007, 41, 2145-2155. [CrossRef] 
65. Wehner, B.; Wiedensohler, A. Long term measurements of submicrometer urban aerosols: Statistical analysis for correlations with meteorological conditions and trace gases. Atmos. Chem. Phys. 2003, 3, 867-879. [CrossRef]

66. Wehner, B.; Wiedensohler, A.; Tuch, T.M.; Wu, Z.J.; Hu, M.; Slanina, J.; Kiang, C.S. Variability of the aerosol number size distribution in Beijing, China: New particle formation, dust storms, and high continental background. Geophys. Res. Lett. 2004, 31, L22108. [CrossRef]

67. Mølgaard, B.; Birmili, W.; Clifford, S.; Massling, A.; Eleftheriadis, K.; Norman, M.; Vratolis, S.; Wehner, B.; Corander, J.; Hämeri, K.; et al. Evaluation of a statistical forecast model for size-fractionated urban particle number concentrations using data from five European cities. J. Aerosol Sci. 2013, 66, 96-110. [CrossRef]

68. Ragettli, M.S.; Corradi, E.; Braun-Fahrländer, C.; Schindler, C.; de Nazelle, A.; Jerrett, M.; Ducret-Stich, R.E.; Künzli, N.; Phuleria, H.C. Commuter exposure to ultrafine particles in different urban locations, transportation modes and routes. Atmos. Environ. 2013, 77, 376-384. [CrossRef]

69. Velasco, E.; Tan, S.H. Particles exposure while sitting at bus stops of hot and humid Singapore. Atmos. Environ. 2016, 142, 251-263. [CrossRef]

70. Cheng, Y.H.; Chang, H.P.; Hsieh, C.J. Short-term exposure to PM10, PM2.5, ultrafine particles and CO2 for passengers at an intercity bus terminal. Atmos. Environ. 2011, 45, 2034-2042. [CrossRef]

71. Hess, D.B.; Ray, P.D.; Stinson, A.E.; Park, J. Determinants of exposure to fine particulate matter (PM2.5) for waiting passengers at bus stops. Atmos. Environ. 2010, 44, 5174-5182. [CrossRef]

72. Hamdi, M.R.; Bdour, A.; Tarawneh, Z. Diesel quality in Jordan: Impacts of vehicular and industrial emissions on urban air quality. Environ. Eng. Sci. 2008, 25, 1333-1343. [CrossRef]

73. Hudda, N.; Fruin, S.A. Carbon dioxide accumulation inside vehicles: The effect of ventilation and driving conditions. Sci. Total Environ. 2018, 610-611, 1448-1456. [CrossRef] [PubMed]

74. Leavey, A.; Reed, N.; Patel, S.; Bradley, K.; Kulkarni, P.; Biswas, P. Comparing on-road Real-time Simultaneous in-cabin and Outdoor Particulate and Gaseous Concentrations for a Range of Ventilation Scenarios. Atmos. Environ. 2017, 166, 130-141. [CrossRef] [PubMed]

75. Li, F.; Lee, E.S.; Zhou, B.; Liu, J.; Zhu, Y. Effects of the window openings on the micro-environmental condition in a school bus. Atmos. Environ. 2017, 167, 434-443. [CrossRef]

76. Alameddine, I.; Abi Esber, L.; Bou Zeid, E.; Hatzopoulou, M.; El-Fadel, M. Operational and environmental determinants of in-vehicle CO and PM2.5 exposure. Sci. Total Environ. 2016, 551-552, 42-50. [CrossRef] [PubMed]

77. Ding, H.; Zhang, Y.; Sun, H.; Feng, L. Analysis of PM2.5 distribution and transfer characteristics in a car cabin. Energy Build. 2016, 127, 252-258. [CrossRef]

78. Lee, E.S.; Stenstrom, M.K.; Zhu, Y. Ultrafine particle infiltration into passenger vehicles. Part I: Experimental evidence. Transp. Res. D 2015, 38, 156-165. [CrossRef]

79. Lee, E.S.; Stenstrom, M.K.; Zhu, Y. Ultrafine particle infiltration into passenger vehicles. II: Model analysis. Transp. Res. D 2015, 38, 144-155. [CrossRef]

80. Shu, S.; Yu, N.; Wang, Y.; Zhu, Y. Measuring and modeling air exchange rates inside taxi cabs in Los Angeles, California. Atmos. Environ. 2015, 122, 628-635. [CrossRef]

81. Abi-Esber, L.; El-Fadel, M. Indoor to outdoor air quality associations with self pollution implications inside passenger car cabins. Atmos. Environ. 2013, 81, 450-463. [CrossRef]

82. Bigazzi, A.Y.; Figliozzi, M.A. Impacts of freeway traffic conditions on in-vehicle exposure to ultrafine particulate matter. Atmos. Environ. 2012, 60, 495-503. [CrossRef]

83. Hudda, N.; Eckel, S.P.; Knibbs, L.D.; Sioutas, C.; Delfino, R.J.; Fruin, S.A. Linking in-vehicle ultrafine particle exposures to on-road concentrations. Atmos. Environ. 2012, 59, 578-586. [CrossRef] [PubMed]

84. Knibbs, L.D.; de Dear, R.J. Exposure to ultrafine particles and PM2.5 in four Sydney transport modes. Atmos. Environ. 2010, 44, 3224-3227. [CrossRef]

85. Pattinson, W.; Longley, I.; Kingham, S. Using mobile monitoring to visualise diurnal variation of traffic pollutants across two near-highway neighbourhoods. Atmos. Environ. 2014, 94, 782-792. [CrossRef]

86. Li, B.; Lei, X.N.; Xiu, G.L.; Gao, C.Y.; Gao, S.; Qian, N.S. Personal exposure to black carbon during commuting in peak and off-peak hours in Shanghai. Sci. Total Environ. 2015, 524-525, 237-245. [CrossRef] [PubMed]

87. MacNaughton, P.; Melly, S.; Vallarino, J.; Adamkiewicz, G.; Spengler, J.D. Impact of 731 bicycle route type on exposure to traffic-related air pollution. Sci. Total Environ. 2014, 490, 37-43. [CrossRef] [PubMed] 
88. Kumar, P.; Rivas, I.; Sachdeva, L. Exposure of in-pram babies to airborne particles during morning drop-in and afternoon pick-up of school children. Environ. Pollut. 2017, 224, 407-420. [CrossRef]

89. Okokon, E.O.; Yli-Tuomi, T.; Turunen, A.W.; Taimisto, P.; Pennanen, A.; Vouitsis, I.; Samaras, Z.; Voogt, M.; Keuken, M.; Lanki, T. Particulates and noise exposure during bicycle, bus and car commuting: A study in three European cities. Environ. Res. 2017, 154, 181-189. [CrossRef]

90. Nazelle, A.; Fruin, S.; Westerdahl, D.; Mareinez, D.; Ripoll, A.; Kubesch, N.; Nieuwenhuijsen, M. A travel mode comparison of commuters' exposures to air pollutants in Barcelona. Atmos. Environ. 2012, 59, 151-159. [CrossRef]

91. Panis, I.L.; de Geus, B.; Vandenbulcke, G.; Willems, H.; Degraeuwe, B.; Bleux, N.; Mishra, V.; Thomas, I.; Meeusen, R. Exposure to particulate matter in traffic: A comparison of cyclists and car passengers. Atmos. Environ. 2010, 44, 2263-2270. [CrossRef]

92. Dons, E.; Int Panis, I.L.; Poppel, M.V.; Theunis, J.; Wets, G. Personal exposure to Black Carbon in transport microenvironments. Atmos. Environ. 2012, 55, 392-398. [CrossRef]

93. Quiros, D.C.; Lee, E.S.; Wang, R.; Zhu, Y. Ultrafine particle exposures while walking, cycling, and driving along an urban residential roadway. Atmos. Environ. 2013, 73, 185-194. [CrossRef]

94. Ham, W.; Vijayan, A.; Schulte, N.; Herner, J.D. Commuter exposure to PM2.5, BC, and UFP in six common transport microenvironments in Sacramento, California. Atmos. Environ. 2017, 167, 335-345. [CrossRef]

95. Boarnet, M.G.; Houston, D.; Edwards, R.; Princevac, M.; Ferguson, G.; Pan, H.; Bartolome, C. Fine particulate concentrations on sidewalks in five Southern California cities. Atmos. Environ. 2011, 45, 4025-4033. [CrossRef]

96. Hankey, S.; Marshall, J.D. On-bicycle exposure to particulate air pollution: Particle number, black carbon, PM2.5, and particle size. Atmos. Environ. 2015, 122, 65-73. [CrossRef]

97. Apte, J.S.; Kirchstetter, T.W.; Reich, A.H.; Deshpande, S.J.; Kaushik, G.; Chel, A.; Marshall, J.D.; Nazaroff, W.W. Concentrations of fine, ultrafine, and black carbon particles in auto-rickshaws in New Delhi, India. Atmos. Environ. 2011, 45, 4470-4480. [CrossRef]

98. Goel, R.; Gani, S.; Guttikunda, S.K.; Wilson, D.; Tiwari, G. On-road PM2.5 pollution exposure in multiple transport microenvironments in Delhi. Atmos. Environ. 2015, 123, 129-138. [CrossRef]

99. Qiu, Z.; Xu, X.; Song, J.; Luo, Y.; Zhao, R.; Zhou, B.X.W.; Li, X.; Hao, Y. Pedestrian exposure to traffic PM on different types of urban roads: A case study of Xi'an, China. Sustain. Cities Soc. 2017, 32, 475-485. [CrossRef]

100. Qiu, Z.; Song, J.; Xu, X.; Luo, Y.; Zhao, R.; Zhou, W.; Xiang, B.; Hao, Y. Commuter exposure to particulate matter for different transportation modes in Xi'an, China. Atmos. Pollut. Res. 2017, 8, 940-948. [CrossRef]

101. Huang, J.; Deng, F.; Wu, S.; Guo, X. Comparisons of personal exposure to PM2.5 and CO by different commuting modes in Beijing, China. Sci. Total Environ. 2012, 425, 52-59. [CrossRef]

102. Betancourt, R.M.; Galvis, B.; Balachandran, S.; Ramos-Bonilla, J.P.; Sarmiento, O.L.; Gallo-Murcia, S.M.; Contreras, Y. Exposure to fine particulate, black carbon, and particle number concentration in transportation microenvironments. Atmos. Environ. 2017, 157, 135-145. [CrossRef]

103. Odeh, I.; Hussein, T. Activity pattern of urban adult students in an Eastern Mediterranean Society. Int. J. Environ. Res. Public Health 2016, 13, E960. [CrossRef] [PubMed]

104. Hussein, T.; Paasonen, P.; Kulmala, M. Activity pattern of a selected group of school occupants and their family members in Helsinki-Finland. Sci. Total Environ. 2012, 425, 289-292. [CrossRef] [PubMed]

105. Knibbs, L.D.; Cole-Hunter, T.; Morawska, L. A review of commuter exposure to ultrafine particles and its health effects. Atmos. Environ. 2011, 45, 2611-2622. [CrossRef]

106. Lim, S.; Dirks, K.N.; Salmond, J.A.; Xie, S. Determinants of spikes in ultrafine particle concentration whilst commuting by bus. Atmos. Environ. 2015, 112, 1-8. [CrossRef]

107. Both, A.F.; Westerdahl, D.; Fruin, S.; Haryanto, B.; Marshall, J.D. Exposure to carbon monoxide, fine particle mass, and ultrafine particle number in Jakarta, Indonesia: Effect of commute mode. Sci. Total Environ. 2013, 443, 965-972. [CrossRef]

108. Zhang, Q.; Fischer, H.J.; Weiss, R.E.; Zhu, Y. Ultrafine particle concentrations in and around idling school buses. Atmos. Environ. 2013, 69, 65-75. [CrossRef]

109. Liu, L.J.S.; Phuleria, H.C.; Webber, W.; Davey, M.; Lawson, D.R.; Ireson, R.G.; Zielinska, B.; Ondov, J.M.; Weaver, C.S.; Lapin, C.A.; et al. Quantification of self pollution from two diesel school buses using three independent methods. Atmos. Environ. 2010, 44, 3422-3431.

110. Zhang, Q.; Zhu, Y. Measurements of ultrafine particles and other vehicular pollutants inside school buses in South Texas. Atmos. Environ. 2010, 44, 253-261. [CrossRef] 
111. Knibbs, L.D.; de Dear, R.J.; Morawska, L. Effect of cabin ventilation rate on ultrafine particle exposure inside automobiles. Environ. Sci. Technol. 2010, 44, 3546-3551. [CrossRef]

112. Costabile, F.; Alas, H.; Aufderheide, M.; Avino, P.; Amato, F.; Argentini, S.; Barnaba, F.; Berico, M.; Bernardoni, V.; Biondi, R.; et al. First results of the "Carbonaceous aerosol in Rome and Environs (CARE)" experiment: Beyond current standards for PM10. Atmosphere 2017, 8, 249. [CrossRef]

113. Alas, H.D.; Weinhold, K.; Costabile, F.; Di Ianni, A.; Müller, T.; Pfeifer, S.; Di Liberto, L.; Turner, J.R.; Wiedensohler, A. Methodology for high quality mobile measurement with focus on black carbon and particle mass concentrations. Atmos. Meas. Tech. Disc. 2019. [CrossRef]

114. Messier, K.P.; Chambliss, S.E.; Gani, S.; Alvarez, R.; Brauer, M.; Choi, J.J.; Hamburg, S.P.; Kerckhoffs, J.; La Franchi, B.; Lunden, M.M.; et al. Mapping air pollution with google street view cars: Efficient Approaches with mobile monitoring and land use regression. Environ. Sci. Technol. 2018, 52, 12563-12572. [CrossRef]

115. Hankey, S.; Sforza, P.; Pierson, M. Using mobile monitoring to develop hourly empirical models of particulate air pollution in a rural Appalachian community. Environ. Sci. Technol. 2019, 53, 4305-4315. [CrossRef] [PubMed]

(C) 2019 by the authors. Licensee MDPI, Basel, Switzerland. This article is an open access article distributed under the terms and conditions of the Creative Commons Attribution (CC BY) license (http://creativecommons.org/licenses/by/4.0/). 